\title{
Systematic and biostratigraphy of the genera Parasolenopleura, Badulesia, and Pardailhania in the Iberian Chains: a useful zonation for the Miaolingian Series (former middle Cambrian) in the Mediterranean region
}

\author{
Juan B. CHIRIVELLA MARTORELL ${ }^{1}$, Eladio LIÑÁN ${ }^{2}, M^{a}$ Eugenia DIES ÁLVAREZ \& \\ Rodolfo GOZALO ${ }^{\prime *}$
}

${ }^{1}$ Departamento de Botánica y Geología, Universitat de València, C/ Dr. Moliner 50, E-46100- Burjassot, Spain; juamar@iesorriols.com, rodolfo.gozalo@uv.es

${ }^{2}$ Departamento de Ciencias de la Tierra-IUCA. Universidad de Zaragoza, E-50009 Zaragoza, Spain; linan@unizar.es

${ }^{3}$ Departamento de Didácticas Específicas-IUCA. Universidad de Zaragoza, C/ Pedro Cerbuna 12, E-50009-Zaragoza, Spain; medies@unizar.es

*Corresponding author

Chirivella Martorell, J.B., Liñán, E., Dies Álvarez, Ma.E. \& Gozalo, R. 2020. Systematic and biostratigraphy of the genera Parasolenopleura, Badulesia, and Pardailhania in the Iberian Chains: a useful zonation for the Miaolingian Series (former middle Cambrian) in the Mediterranean region. [Sistemática y bioestratigrafía de los géneros Parasolenopleura, Badulesia y Pardailhania en las Cadenas Ibéricas: una zonación útil para la Serie Miaolingiense (antiguo Cámbrico medio) en la región Mediterránea]. Spanish Journal of Palaeontology, 35 (1), 1-28.

Manuscript received 21 February 2019

Manuscript accepted 2 October 2019 https://doi.org/10.7203/sjp.35.1.17115

(C) Sociedad Española de Paleontología ISSN 2255-0550

\begin{abstract}
The trilobite species of three genera included in the Family Solenopleuridae: Parasolenopleura, Badulesia, and Pardailhania are revised. These genera have a great biostratigraphic interest due to their broad distribution in the Miaolingian Series (former middle Cambrian) of the Mediterranean Subprovince and because they constitute an evolutionary lineage, that facilitates an accurate regional correlation. Two of these genera (Pardailhania and Badulesia) have been used to define middle Cambrian zones in Spain (lower and middle Caesaraugustan, equivalent to the uppermost Wuliuan and the lower Drumian stages). Although, all authors have been using the same species to establish the Mediterranean biozonation of this interval time, the zone concept has been modified since Sdzuy's original idea. A thorough study of three localities from the Iberian
\end{abstract}

RESUMEN

Se revisan las especies de tres géneros de trilobites pertenecientes a la Familia Solenopleuridae: Parasolenopleura, Badulesia y Pardailhania. Estos géneros tienen un gran interés bioestratigráfico debido a su ámplia distribución en la Serie Miaolingiense (antiguo Cámbrico medio) de la Subprovincia Mediterránea y por constituir un linaje evolutivo que facilita una correlación regional precisa. Dos de estos géneros (Pardailhania y Badulesia) han sido utilizados para definir zonas del Cámbrico medio en España (Caesaraugustiense inferior y medio, equivalente a la parte más alta del piso Wuliuense y al Drumiense inferior). A pesar de que todos los autores han utilizado las mismas especies para establecer la biozonación Mediterránea, el concepto de zona ha sido modificado desde la idea original de Sdzuy. El estudio completo de tres localidades de las Cadenas Ibéricas 
Chains (Murero, Jarque, and Villafeliche) have allowed us to revise the lower and middle Caesaraugustan zonation in the Iberian Chains and for extension, in the Mediterranean region by comparison with the other localities where those genera are recorded. We propose now a review zonation based on trilobite phylozones, including new stratigraphic and systematic data from the Iberian Chains in order to clarify the intercontinental correlation of this time interval.

Keywords: Trilobites, systematic, biostratigraphy, WuliuanDrumian (Miaolingian), Mediterranean region.
(Murero, Jarque y Villafeliche) nos ha permitido revisar la zonación del Caesaraugustiense inferior y medio en las Cadenas Ibéricas y por extensión, en la región Mediterránea por comparación con otras localidades dónde estos géneros se han registrado. Nosotros proponemos una revisión de la zonación basada en filozonas de trilobites, incluyendo nuevos datos estratigráficos y sistemáticos de las Cadenas Ibéricas con el objeto de clarificar la correlación intercontinental de este intervalo de tiempo.

Palabras clave: Trilobites, sistemática, biostratigrafía, Wuliuense-Drumiense (Miaolingiense), región Mediterranea.

\section{INTRODUCTION}

The Solenopleuridae Parasolenopleura Westergård, 1953, Badulesia Sdzuy, 1968, and Pardailhania Thoral, 1947 recorded in the Miaolingian Series (former middle Cambrian) of the Iberian Chains are revised herein. The first of them is probably the ancestor of the Subfamily Solenopleuropsinae Thoral, 1947; the other two genera are the oldest representatives of this subfamily, including Sao Barrande, 1846, Solenopleuropsis Thoral, 1947, and Velieuxia Courtessole, 1973. Their good record and broad geographic distribution in the Mediterranean Subprovince (sensu Sdzuy et al., 1999) make them useful biostratigraphic markes for this region. Badulesia and Pardailhania have been used to establish the classical biozonation for the lower and middle Caesaraugustan in the Mediterranean Subprovince (Fig. 1). Since the use of concepts like zones and/or biozones are slightly different depending on the author, we will follow the definition in Gozalo et al. (2011b).

In the Iberian Chains, for the interval studied (middle Leonian to middle Caesaraugustan), we have found nine

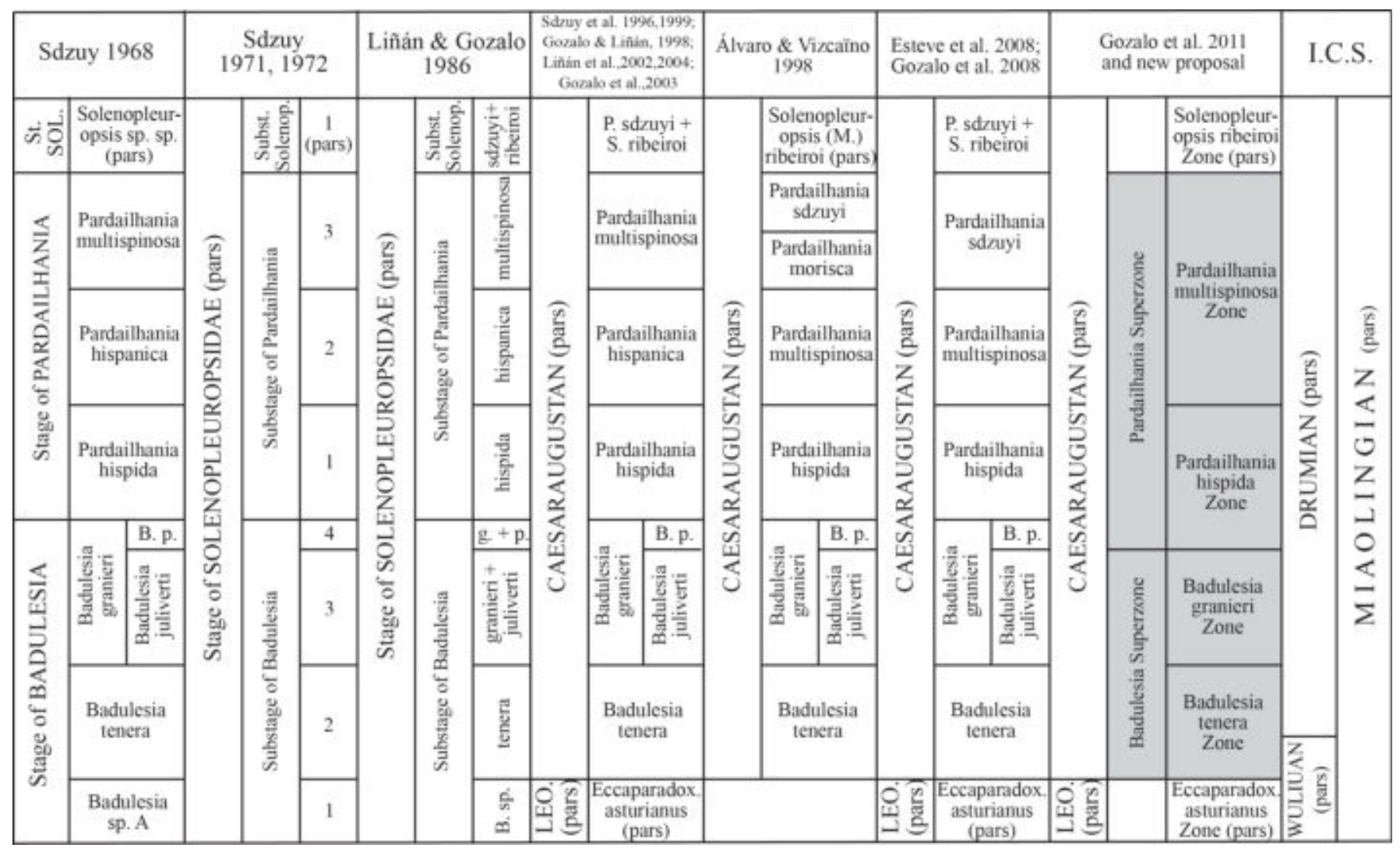

Figure 1. Biostratigraphical subdivisions of the level studied in the lower and middle Caesaraugustan of Spain and France (Miaolingian Series) in a historical context. 
Solenopleuridae species, that in stratigraphical order are Parasolenopleura cf. wurmi Geyer, 2017, Parasolenopleura aculeata (Angelin, 1851), Badulesia tenera (Hartt in Dawson, 1868), Badulesia granieri (Thoral, 1935), Badulesia paschi (Sdzuy, 1958), Pardailhania hispida (Thoral, 1935), Pardailhania multispinosa Thoral, 1948, Pardailhania morisca Álvaro, 1996, and Pardailhania sdzuyi Liñán \& Gozalo, 1986. Both Parasolenopleura species have been identified for the first time in the Iberian Chains. P. aculeata was defined in Sweden where it is restricted to the Ptychagnostus gibbus Zone (Weidner \& Nielsen, 2009). Also, P. aculeata has been found together with $B$. tenera in Sierra de Córdoba (Spain) (Liñán et al., 1995b) and Avalonia (Fletcher, 2006), the other species are endemic to the Mediterranean subprovince (Sdzuy et al., 1999; Gozalo et al., 2011b).

The intensive sampling and deep study of three sections in the Iberian Chains [Rambla de Valdemiedes 1 (RV1), Jarque 1 (J1) and Villafeliche 1 (Vi1)] together with the complementary data from other localities (biz Ateca, Borobia, Mesones, Murero and Purujosa) have permitted us to establish the morphological variation range of the species using evolutionary criteria. Furthermore, the detailed analysis of the stratigraphic distribution of these species could allow us to redefine the zonation for the lower and middle Caesaraugustan (Miaolingian Series) in the Iberian Chains, which is applicable in the Mediterranean region.

\section{GEOLOGICAL AND STRATIGRAPHIC SETTING}

The Iberian Chains (NE Spain) represent one of the best places to study Cambrian fossils from lower Cambrian to Furongian in the Mediterranean region. The Cambrian rocks were discovered by Verneuil (1862) who found the Primordial Fauna in the locality of Murero (Iberian Chains) (Fig. 2). Syntheses on the Cambrian palaeontological record of the Iberian Chains have been published by Liñán et al. (1996c, 2008) and Gozalo et al. (2008).

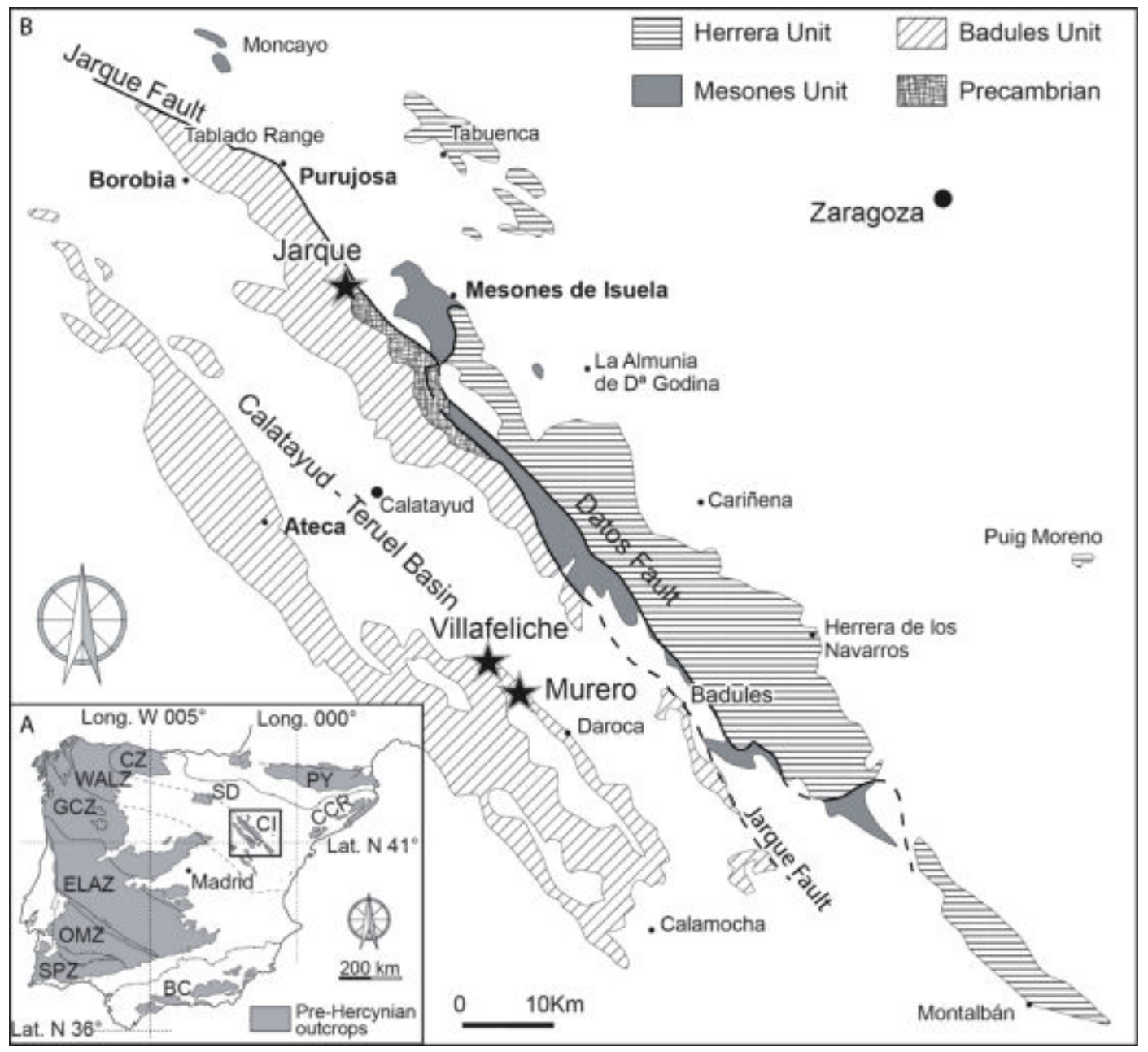

Figure 2. Map of the Iberian Peninsula (a) showing pre-Hercynian outcrop areas and the location of the studied sections in the Iberian Chains (b). Modified from Gozalo \& Liñán (1988). 
The levels studied herein belong to the Mesones Group (Bilbilian to lower Languedocian; i.e. Stage 4 of Cambrian to Drumian). This stratigraphic group is widely known as a rich source of trilobite species and other fossils such as bradoriids, nektaspids, brachiopods, echinoderms, sponges, hyoliths, palaeoscolecids, lobopods or radiodontans, algae and ichnofossils (Sdzuy, 1961; Liñán \& Gozalo, 1986; Mergl \& Liñán, 1986; Gámez-Vintaned \& Mayoral, 1992, 1995; Liñán et al., 1996c, 2008; Liñán \& Mergl, 2001; García-Bellido et al., 2007, 2011; Gozalo et al., 2004, 2008, 2018; Zamora, 2010; Gámez-Vintaned et al., 2011; Mergl \& Zamora, 2012; Pates \& Daley, 2017; Gámez-Vintaned \& Zhuravlev, 2018). The Mesones Group is subdivided into three formations: Valdemiedes, Mansilla and Murero formations (Liñán et al., 1992, 2002, 2004). The trilobites species revised herein have been found from the top of the Valdemiedes Formation to the lower part of the Murero Formation and range from middle Leonian to middle Caesaraugustan (equivalent to Wuliuan to lower Drumian stages; Miaolingian Series). The stratigraphic distribution of trilobites in the Iberian Chains has been plotted (Fig. 3) from the Leonian to lower upper Caesaraugustan, along with the tentative correlation with the uppermost Stage 4, Wulian, and lower Drumian (Liñán et al., 1996c, 2008; Dies et al., 2004; Gozalo et al., 2007, 2011b, 2013).

Although the material has been collected from several sections and localities in the Iberian Chains (Ateca, Borobia, Jarque, Mesones de Isuela, Murero, Purujosa, and Villafeliche) and Sierra Morena (Fuente de Bernardo 1 in Córdoba and La Albuera 1 in Badajoz), three sections of them have been studied in detail (Figs 4-6): Rambla de

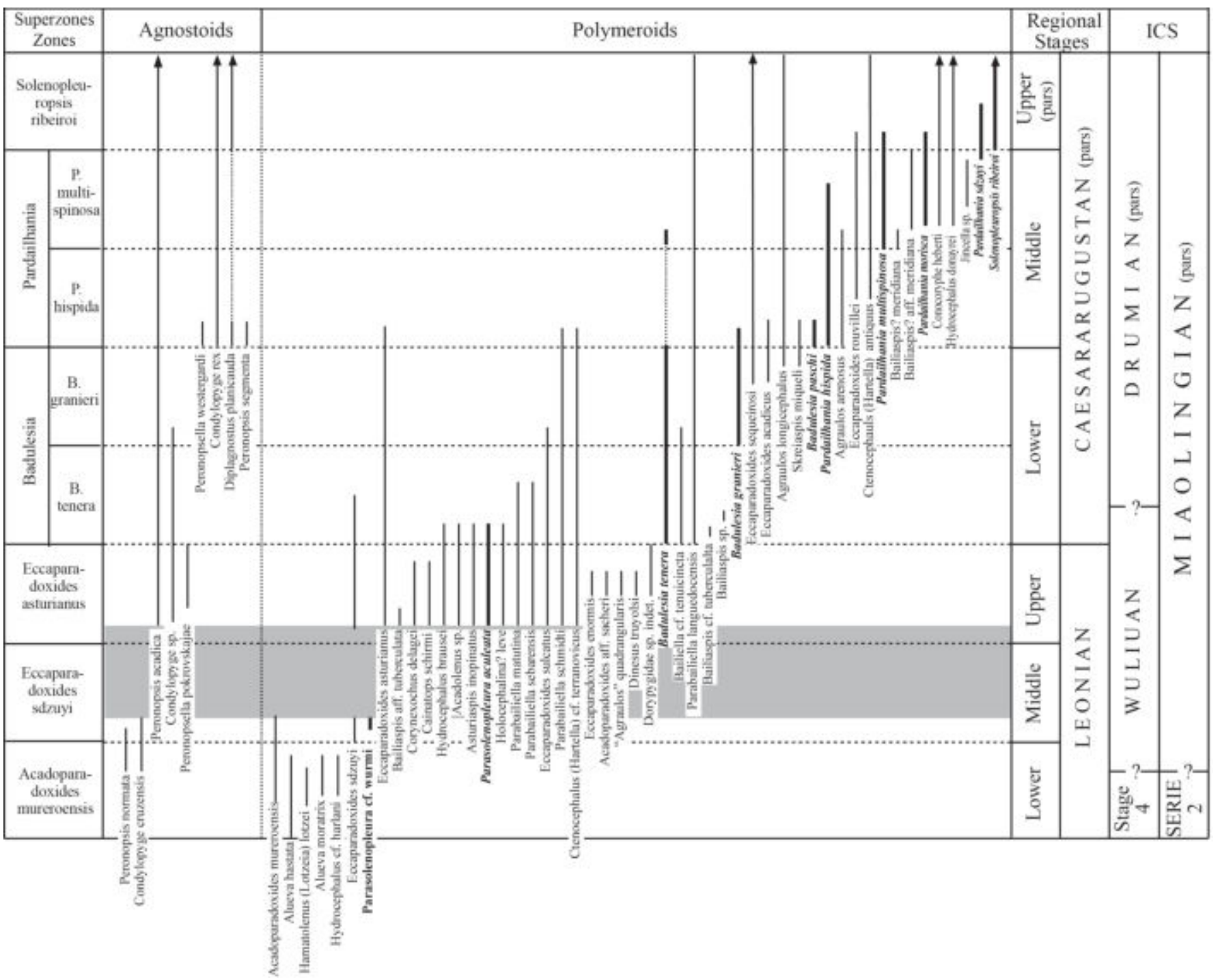

Figure 3. Stratigraphic distribution of trilobite species between the Leonian and the early middle Caesaraugustan (uppermost Stage 4 of Cambrian to Drumian). Names of species revised herein are highlighted in bold. 


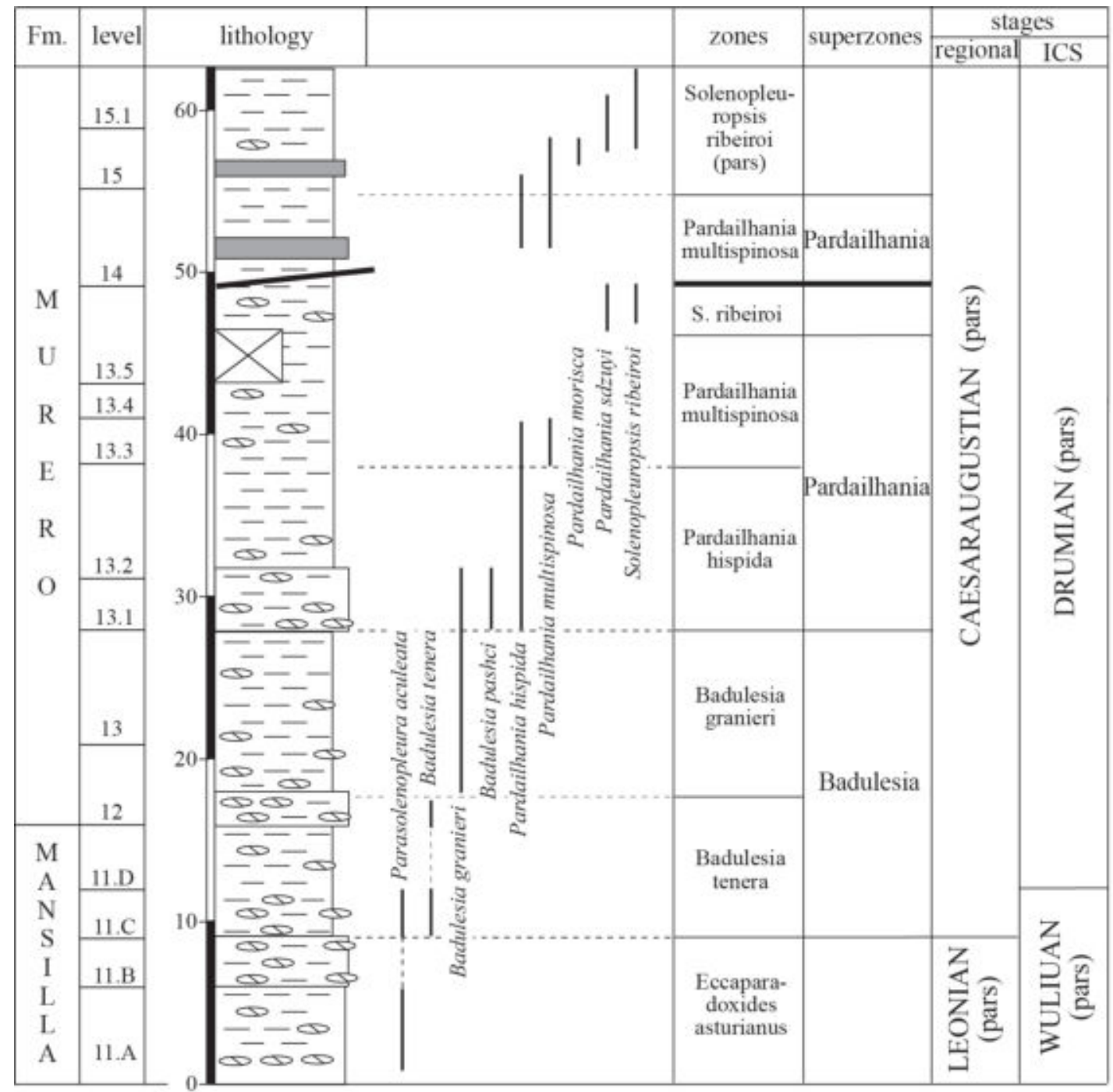

Figure 4. Stratigraphy of the Mansilla Formation and lower part of the Murero Formation in the Rambla de Valdemiedes 1 section - RV1 (modified from Liñán \& Gozalo, 1986; Liñán et al., 2008; Gozalo, 2017). Levels with Parasolenopleura, Badulesia, and Pardailhania species are indicated by vertical lines. See Figure 5 for legend.

Valdemiedes 1 in Murero (RV1, Fig. 4) (Liñán \& Gozalo, 1986, Gozalo et al., 1996; Liñán et al., 2008; Gozalo, 2017), Villafeliche 1 (Vil, Fig. 5) (Gozalo et al., 1993, 1996; Dies \& Gozalo, 2004 ) and Jarque 1 (J1, Fig. 6) (Liñán et al., 1996b, 2008; Chirivella-Martorell et al., 2003).

\section{SYSTEMATIC PALAEONTOLOGY}

The material studied in this work is deposited in the Museo de Ciencias Naturales de la Universidad de Zaragoza (University of Zaragoza Museum of Natural Sciences), Spain - formerly known (until 2012) as Museo Paleontológico de la Universidad de Zaragoza (University of Zaragoza Museum of Palaeontology; see Canudo, 2018).
Part of the material studied herein has been previously published (see synonym list). Nonetheless, the majority of the specimens correspond to the sampling carried out during the completion of the doctoral thesis of ChirivellaMartorell (2008) and subsequent field campaigns.

These sampling were accurately bed-by-bed and it has allowed us to observe that the stratigraphic order of appearance of species is always the same in the studied sections. In addition, it has been possible to verify the morphological variation of the different species both in the same bed and in successive beds. The new material of Solenopleuropsinae found presents the same morphological features as the previously studied material. This reinforces the evolutionary concept proposed by Sdzuy (1968) for this group since the morphological changes, variations in the number of tubercles of the preglabellar area, and 


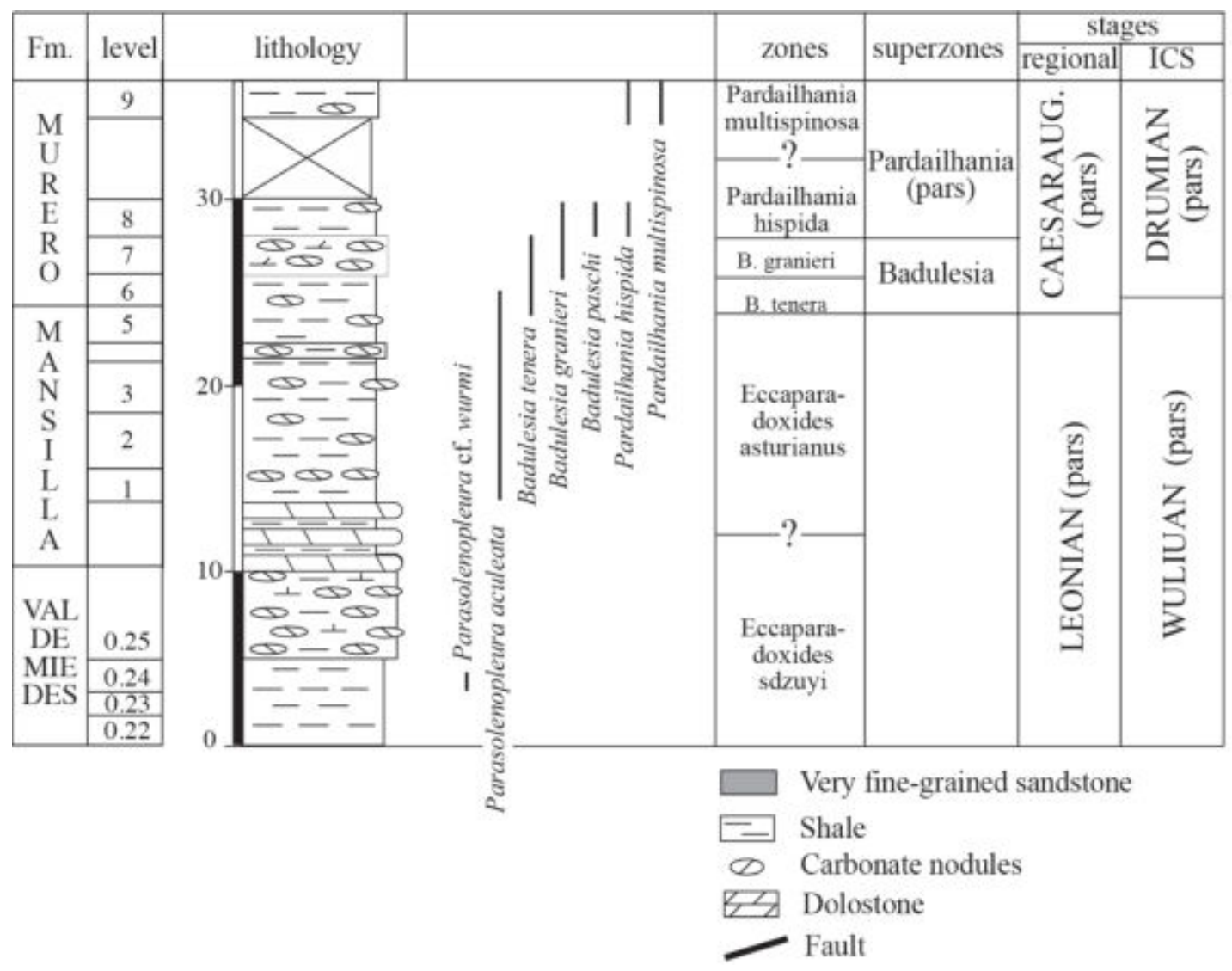

Figure 5. Stratigraphy of the upper Valdemiedes Formation, Mansilla Formation, and lower part of the Murero Formation in the Villafeliche 1 section - Vil (modified from Gozalo et al. 1993, 1996; Dies \& Gozalo, 2004). Levels with Parasolenopleura, Badulesia, and Pardailhania species are indicated by vertical lines.

presence or absence of ridges in the surface of fixigena and glabella follow a pattern in their development from the oldest specimens to the most modern. This fact has allowed designing an evolutionary scheme of the morphological variation range of the species using evolutionary criteria and the previous phylogenetic proposals by Sdzuy (1968) and Álvaro \& Vizcaïno (2001) with slight modifications due to the publication of new material of the group (Gozalo et al., 2011a) and the new data represented in Figure 7. This phylogenetic proposal corroborates the adequacy of the biozonation and its consideration as a phylozonation in this work. In addition, in other areas of the Mediterranean Subprovince, although in less detail, it could be verified that the stratigraphic order of appearance of the different species is always the same and, therefore, this zonation is useful throughout the Mediterranean Subprovince.

Order PTYCHOPARIIDA Swinnerton, 1915

Family Solenopleuridae Angelin, 1854

Subfamily Solenopleurinae Angelin, 1854

Genus Parasolenopleura Westegård, 1953
Type species Calymene aculeata Angelin, 1851, by original designation Westergård (1953: 21).

Parasolenopleura aculeata (Angelin, 1851)

(Fig. 8)

* 1851 Calymene aculeata Angelin, 1851; Angelin, p. 23, pl. 19, fig. 2.

1854 Liostracus aculeatus (Angelin); Angelin, p. 27, pl. 19, fig. 2.

1868 Conocephalites orestes Hartt, MS; Hartt in Dawson, p. 648.

1868 Conocephalites ouangondianus Hartt, MS; Hartt in Dawson, p. 651-652, fig. 226.

1868 Conocephalites aurora Hartt, MS; Hartt in Dawson, p. 653.

1868 Conocephalites quadratus Hartt, MS; Hartt in Dawson, p. 654.

1878 Calymene aculeata Angelin, 1851; Angelin, p. 23 , pl. 19, fig. 2 . 


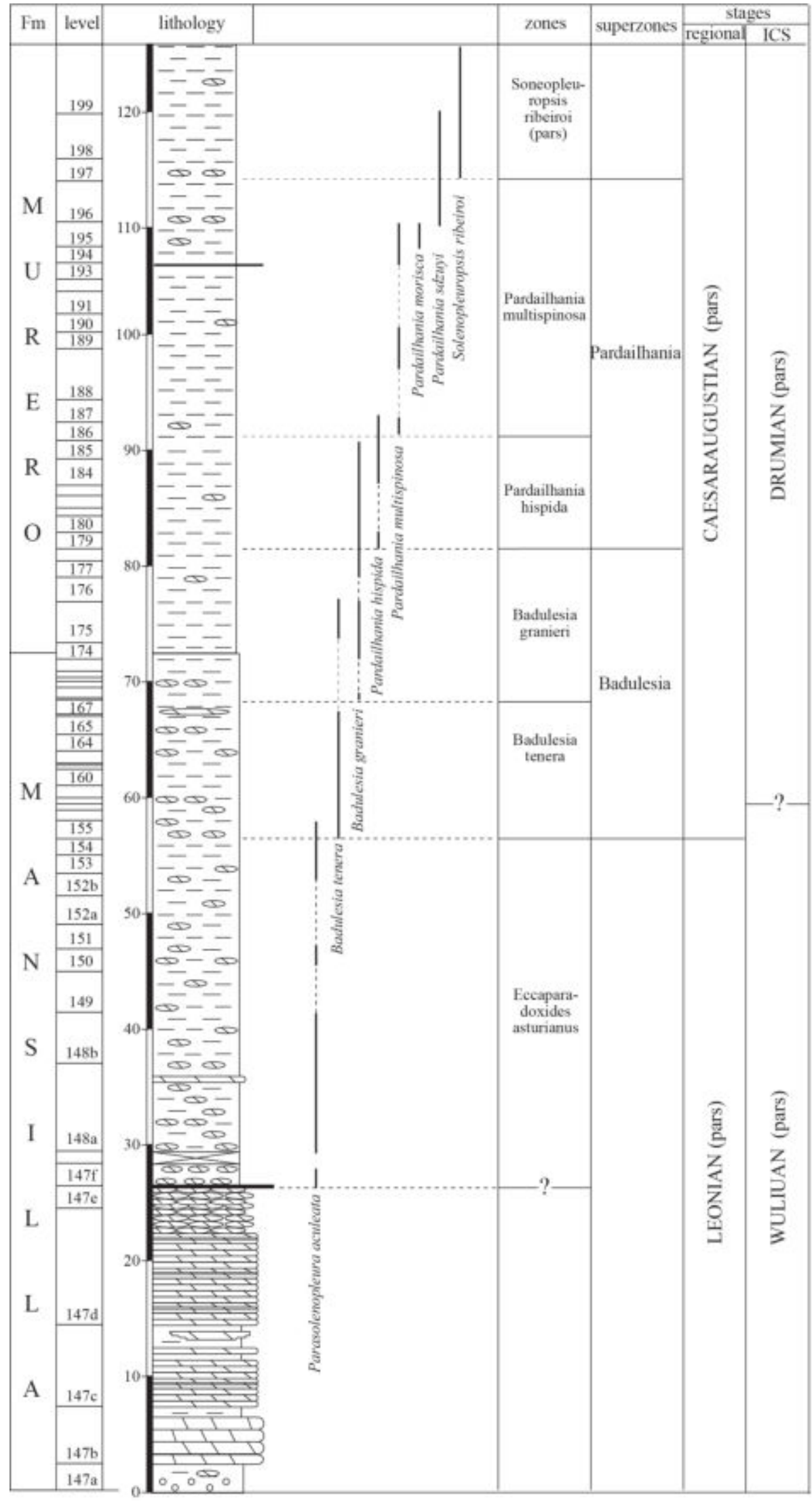

Figure 6. Stratigraphy of the Mansilla Formation and lower part of the Murero Formation in the Jarque 1 section - J1 (modified from Liñán et al., 1996b, 2008) sections. Levels with Parasolenopleura, Badulesia, and Pardailhania species are indicated by vertical lines. See Figure 5 for legend. 


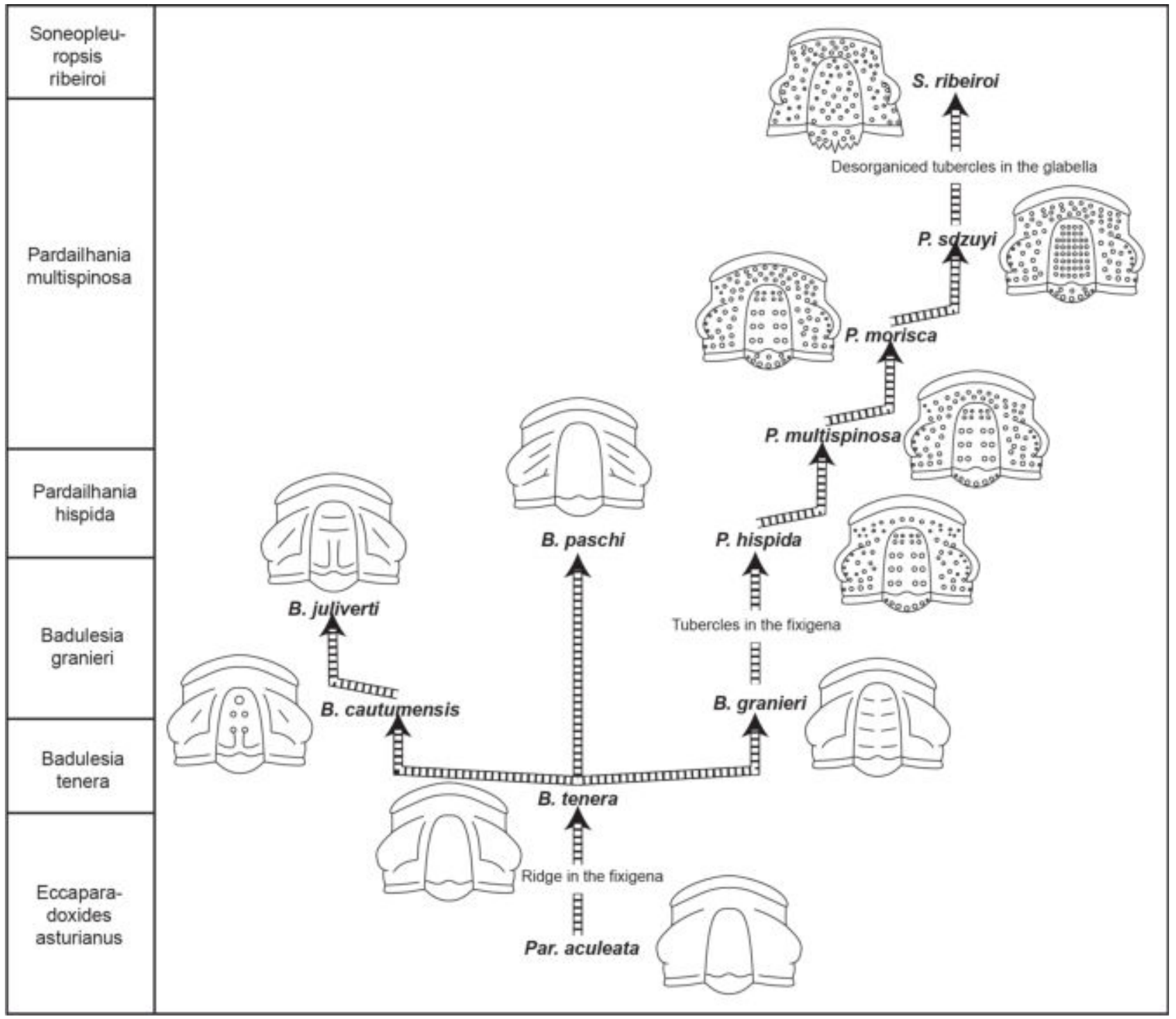

Figure 7. Diagram showing a tentative evolution of the genus Badulesia and Pardailhania, modified from Sdzuy (1968) and Álvaro \& Vizcaïno (2001), including the species Badulesia cautumensis Gozalo et al., 2011a.

1878 Liostracus aculeatus (Angelin); Angelin, p. 27, pl. 19 , fig. 2

? 1878 Liostracus aculeatus (Angelin); Brøgger, p. 46 (30), pl. 3, fig. 3 (cf. Parasolenopleura spinigera Westergård, fide Westergård, 1953, p. 23).

1879 Liostracus aculeatus (Angelin); Linnarsson, p. 11-13, pl. 1, figs. 12-15.

1883 Liostracus aculeatus (Angelin); Linnarsson, p. 22.

1884 Ptychoparia orestes (Hartt); Walcott, p. 37, pl. 5, fig. 4.

1884 Ptychoparia ouangondiana (Hartt); Walcott, p. 37, pl. 5, fig. 4.

1884 Ptychoparia ouangondiana var. aurora (Hartt); Walcott, p. 38, pl. 5, fig. 5.
1884 Ptychoparia orestes (Hartt); Walcott, p. 39, pl. 5, fig. 3 .

1884 Liostracus aculeatus (Angelin); Walcott, pl. 6, fig. 6 .

1888 Liostracus ouangondianus (Hartt); Matthew, pp. 138-142, pl. 1, fig. 4; pl. 22, fig. 7.

1889 Liostracus aculeatus (Angelin); Lesley, p. 351, fig. 1897 Liostracus validus n. sp.; Matthew, p. 179, pl. II figs., 7a-b.

1906 Liostracus aculeatus; Wiman, p. 287. [Listed].

1913 Liostracus aculeatus (Angelin); Walcott, p. 137, pl. 13, fig. 6 .

1929 Liostracus aculeatus (Angelin); Strand, p. 351, pl. 2, fig 5 . 
1937 Andrarina aculeatus (Angelin); Raymond, p. 1106.

1942 Andrarina quadrata (Hartt); Schmidt, pp. 373374, pl. 23, fig. 4.

1944 Andrarina ouangondiana (Hartt); Shimer \& Shrock, p. 605, pl. 276, fig. 26.

1953 Parasolenopleura aculeata (Angelin, 1851); Westergård, p. 23-25, pl. 5, figs. 6-10; pl. 6 figs. 1-4.
1957 Pardailhania sp.; Sdzuy, p. 26, fig. 14.

1958 Solenopleurina aculeata (Angelin); Šnajdr, p. 200.

1966 Parasolenopleura cf. aculeata (Angelin); Rushton, 1966, p. 47, pl. 6, fig. 14.

1966 Parasolenopleura aculeata (Angelin); Sdzuy, p. 72 .

1968 Badulesia n. sp. A; Sdzuy, p. 82-83, 111, table 1.
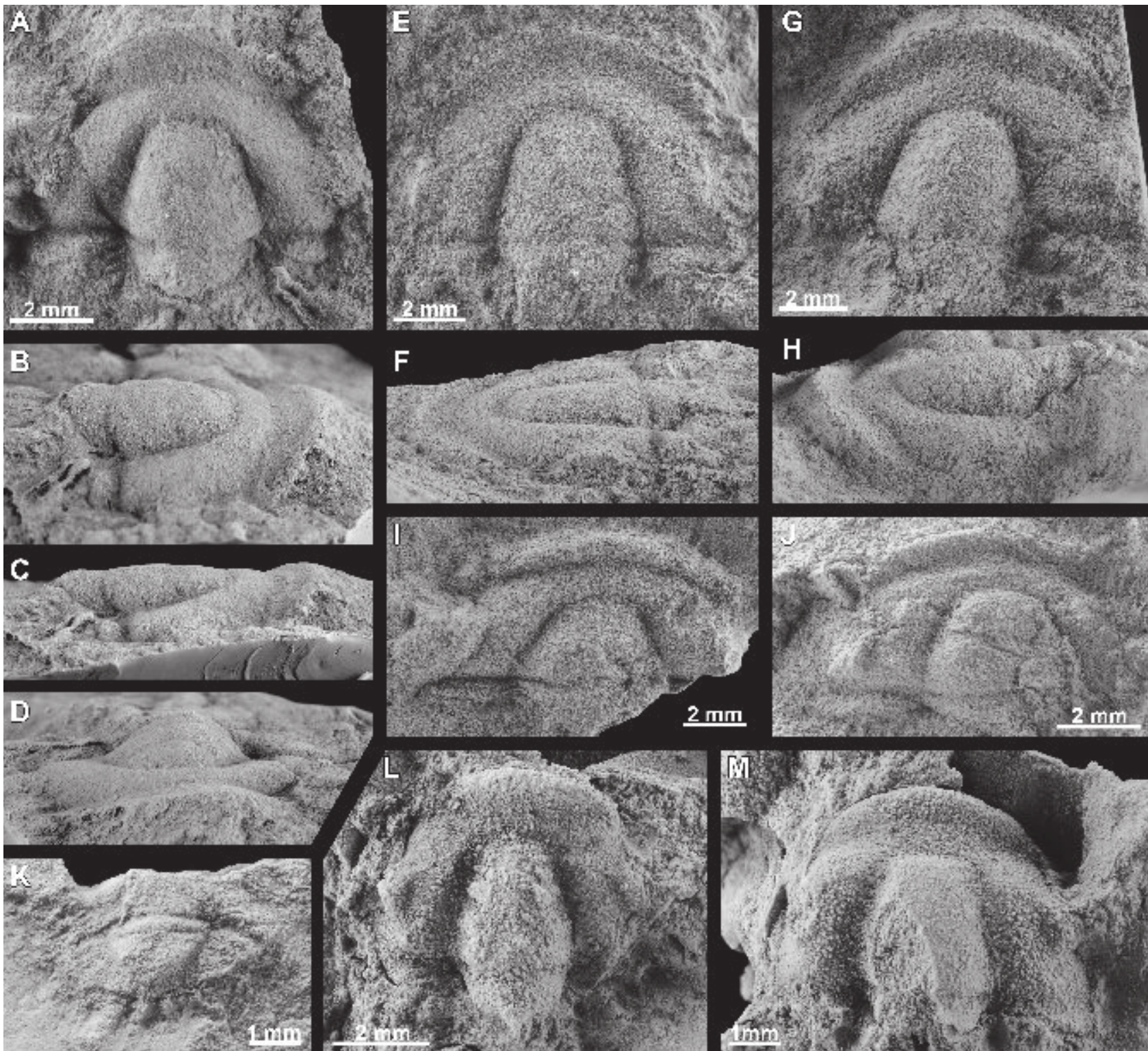

$\underline{\mathbf{m m}}$

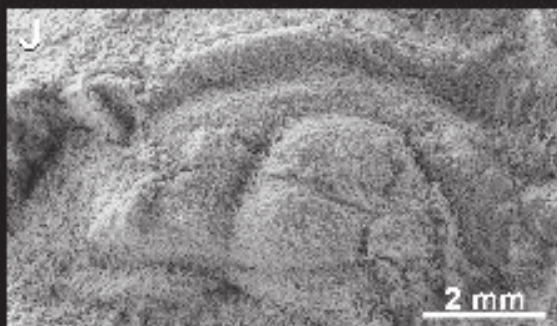

Figure 8. Parasolenopleura aculeata (Angelin, 1851). a-d) Cranidium, latex cast, Mansilla Formation, Jarque 1 Section, MPZ2003/132, dorsal, right and frontal views. e-f) Cranidium, internal mould, Mansilla Formation, Jarque 1 Section, MPZ2003/129, dorsal and left views. g-h) Cranidium, internal mould, Mansilla Formation, Villafeliche 1 Section, MPZ2003/76, dorsal and left views. i) Cranidium, internal mould, Mansilla Formation, Mesones 3 Section, MPZ2003/76, dorsal view. j) Cranidium, internal mould, Mansilla Formation, Jarque 1 Section, MPZ2003/71, dorsal view. k) Pygidium, internal mould, Mansilla Formation, Villafeliche 1 Section, MPZ2003/1456, dorsal view. l) Cranidium, internal mould, Los Villares Formation, Fuente Bernardo 1 Section (Ossa-Morena Zone, Córdoba), MPZ95-31, dorsal view. m) Cranidium, internal mould, Los Villares Formation, Fuente Bernardo 1 Section (OssaMorena Zone, Córdoba), MPZ95-30, dorsal view. 
? 1973 Solenopleurina? cf. aculeata (Angelin); Courtessole, p. 178, pl. 17, fig. 9.

1979 Parasolenopleura aculeata (Angelin); Neben \& Krüger, pl. 115, fig. 12.

v 1986 Badulesia sp.; Liñán \& Gozalo, p. 62, pl. 23, fig. 6 .

1988 Parasolenopleura cf. aculeata (Angelin); Morris, p. 168.

v 1993 Badulesia sp. A sensu Sdzuy, 1968; Gozalo et al., pl. I, figs. 6-7.

1994 Parasolenopleura aculeata (Angelin, 1851); Babcock, p. 106, fig. 21.

1994 Parasolenopleura aculeata (Angelin, 1851); Rudolph, p. 211-212, pl. 26, figs. 10-14.

v 1995a Parasolenopleura sp.; Liñán et al., fig. 21-6.

v 1995b Parasolenopleura aculeata (Angelin, 1851); Liñán et al., p. 229, pl. III, figs.5-7.

v 1996a Parasolenopleura sp.; Liñán et al., fig. 13.

v 2001 Badulesia sp. A; Álvaro \& Vizcaïno, 2001, pl I, fig. 1.

2002 Parasolenopleura aculeata (Angelin, 1851); Schöning, fig. 5.

? 2003 Parasolenopleura cf. aculeata (Angelin); Axheimer \& Ahlberg, p. 150, fig. 7I.

2005 Parasolenopleura aculeata (Angelin, 1851); Fletcher, text-fig. $5 \mathrm{~J}$.

p 2005 Parasolenopleura ouangondiana (Hartt in Dawson, 1868); Fletcher, text-fig. 5.K, 5.L, 5.O.

? 2005 Parasolenopleura? sp.; Dean, p. 40, pl. 9, figs. (r), (s), (u).

2006 Parasolenopleura aculeata Fletcher, 79-80, 86, 117.

2009 Parasolenopleura aculeata (Angelin, 1851); Weidner \& Nielsen, fig. 17F-G

Material and locality. One exuvia with cephalon and four thoracic segments, over 120 cranidia and one pygidium, as internal and external moulds preserved in red and brown dolostone and lutites from Mansilla Formation (Iberian Chains). The specimens revisited herein are housed under references MPZ 3062, MPZ 7876, MPZ 7877, MPZ 17001 and MPZ 17002, and the new material that have not published previously are MPZ 2003/37, MPZ 2003/41 to MPZ 2003/77, MPZ 2003/129, MPZ 2003/132, MPZ 2003/136, MPZ 2007/1456, MPZ 2007/1886 and MPZ 2019/1042 to MPZ 2019/1049.
Remarks. Parasolenopleura aculeata is identified for the first time in the Iberian Chains. This well-known species was defined in Sweden by the accurate description by Westergård (1953). The material studied herein shows the main characteristics of this species sensu Weidner \& Nielsen (2009; p. 267): "the upturned anterior border and well-defined eye ridges". However, the palpebral lobe in the Spanish material is bigger than in the Scandinavian material. We consider this difference an intraspecific variation similar to the wide variations accepted for Parasolenopleura gregaria (Billings, 1865) by Fletcher (2005).

The Spanish material was previously classified as Badulesia sp. A by Sdzuy (1968), Badulesia sp. by Liñán \& Gozalo (1986), Badulesia sp. A sensu Sdzuy, 1968 by Gozalo et al. (1993) and Álvaro \& Vizcaïno (2001), and Parasolenopleura sp. by Liñán et al. (1995a, 1996a). Chirivella-Martorell (2008) revisited this Spanish material and collected new samples of this taxon; he identified those specimens as Parasolenopleura ouangondiana in accordance with the generic assignation by Fletcher (2005).

Several authors have highlighted the similar morphology between Parasolenopleura aculeata and 'Conocephalites' ouangondianus Hartt in Dawson, 1868. Westergård (1953; p. 25) considered that the main difference is the morphology of librigena, while Sdzuy (1968; p. 111) focused the main difference on the anterior border morphology. However, the specimens of $P$. aculeata figured by Strand (1929; pl. 2 fig. 5) and Weidner \& Nielsen (2009; fig. 17F) show the same border morphology than 'Conocephalites' ouangondianus. Furthermore, Strand (1929) and Fletcher (2006) considered $C$. ouangondianus as a junior synonym of $P$. aculeata, idea which we are agree. This variability in the anterior border is shown in samples recorded in the same level (Figs 8a$8 \mathrm{~d}, 8 \mathrm{e}-8 \mathrm{f})$.

Two other species with morphological similarity to $P$. aculeata are P. lusatica Sdzuy, 1970 and P. wurmi Geyer, 2017. P. lusatica shows a plain border and a narrower preglabelar area than P. aculeata. The main differences of P. wurmi Geyer, 2017 to $P$. aculeata are the broader (sag.) pregalbellar field of this species (Geyer, 2017).

Occurrence. Weidner \& Nielsen (2009) summarised in their figure 6 the distribution in Scandinavia of Parasolenopleura aculeata where it has only been recorded in the Ptychagnostus gibbus Zone. Fletcher (2006) cited the presence of $P$. aculeata in the Badulesia tenera, Hartella bucculenta at the base of Paradoxides hicksi Zones in Eastern Newfoundland that correlated with Ptychagnostus gibbus and $P$. atavus-P. fissus from Baltica. Liñán et al. (1995b) reported the presence of P. aculeata in the Los Villares Formation (Fuente Bernardo 1 Section, levels $20 \mathrm{~b}, 22,23,24)$ in the Badulesia tenera and base of $B$. granieri Zones.

The specimens previously classified as Parasolenopleura sp. has been recorded in the Base of level 4 of Playón Beds 
in the Section La Albuera 1 near Zafra (Badajoz province) (Liñán et al., 1995a, 1996a).

The record of $P$. aculeata in the Iberian Chains belongs to Eccaparadoxides asturianus Zone to lowermost Badulesia tenera Zone, Upper Leonian to lowermost Cesaraugusta regional Stages (Liñán \& Gozalo, 1986; Gozalo et al., 1993; Chirivella-Martorell, 2008) correlatables with the Wuliuan Stage.

\section{Parasolenopleura cf. wurmi Geyer, 2017}

(Fig. 9)

v 1993. Asturiaspis sp. 1; Gozalo et al., lám. 1, fig. 3.

? 2008. Parasolenopleura? sp.; Landing et al., 899, figs. $8.9,8.12,8.13,8.16$.

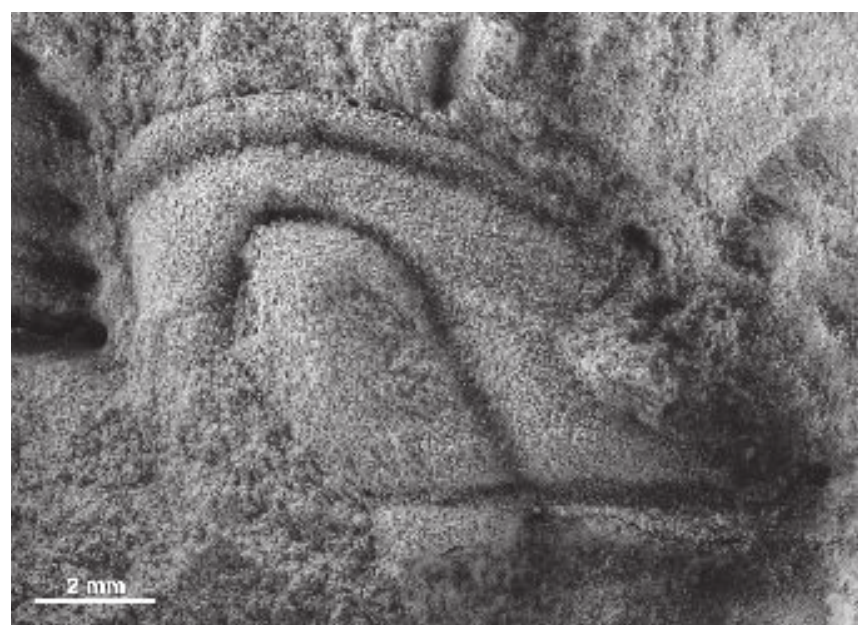

Figure 9. Parasolenopleura cf. wurmi Geyer, 2017, cranidium, internal mould, Valdemiedes Formation, Villafeliche 1 Section, MPZ 7873, dorsal view.

Material and locality. One cranidia as external mould preserved in blue and grey lutite from Valdemiedes Formation (Iberian Chains) in the Villafeliche section (Fig. 4). The specimen studied herein is housed under reference MPZ 7873.

Remarks. Gozalo et al. (1993) classified this specimen as Asturiaspis sp. 1 given the great similarity with this monospecific genus. Although the specimen differs in one of the diagnostic characters used by Sdzuy (1968; $104)$, i.e. the frontal area is almost as long as the glabella without the occipital ring (ca. 85\%); however, juvenile specimens figured by Sdzuy (1968; pl. 5 fig. 9) this relationships is lower (ca. 65\%) and more similar to the aragonese specimen (ca. 50\%). On the other hand, a wide morphological variation has been accepted by Fletcher (2005) at the new diagnosis of Parasolenopleura. The morphology of this specimen is within the accepted variability for the genus. Recently, Geyer (2017) defined Parasolenopleura wurmi which cranidia are very similar to the $P$. cf. wurmi one; where it is possible recognise several of the specific diagnostic characters of this species. The main difference is the narrower preglabellar field and broader anterior border in $P$. wurmi compared with $P$. cf. wurmi that prevent us to a more confident identification.

$P$. cf. wurmi is morphologically very similar to Parasolenopleura? sp. figured and discussed by Landing et al. (2008) from the Fossil Brook Mb. at Beaver Harbour (BHr-IV-6.9) in New Brunswick (Canada), but the scarcity of specimens does not permit an unequivocal identification.

Occurrence. $P$. cf. wurmi has been recorded in the Villafeliche section (Valdemiedes Fm.) in the base of the Eccaparadoxides sdzuy Zone middle Leonian (Wuliuan Stage).

\section{Subfamily Solenopleuropsinae Thoral, 1947 \\ Genus Badulesia Sdzuy, 1968 \\ Type species Liostracus granieri Thoral, 1935, by original designation Sdzuy (1968: 111).}

Remarks. Chirivella Martorell et al. (2003) emended the diagnosis of this genus. These authors proposed as generic characteristics a raised ridge shape of the anterior and lateral borders of the cephalon and at least a pair of internal ridges in the fixigena, together with the ridge formed by the palpebral lobes and ocular ridge union, these characters allow us to differ genus Badulesia from the rest of Solenopleuropsinae genus.

The genus Braintreella Wheeler, 1942 has been proposed as a senior synonym of Badulesia. Thus Bengtson \& Fletcher $(1983 ; 533)$ cited the specie Conocephalites tener as Braintreella tenera. This proposal was discussed by Dean in Martin \& Dean $(1988 ; 21)$, who cited the unpublished thesis of Dr. Fletcher "Evidence for considering Badulesia a junior subjective synonym of Braintreella is not yet published, and for present purposes Badulesia is retained provisionally" [sic].

Geyer \& Landing $(2001 ; 129-131)$ reviewed genus Braintreella and its type species Ptychoparia rogersi Walcott, 1884. They kept only the type species within the genus Braintreella. They considered this genus as a subjective synonym of other solenopleurid genus. But the poor preservation of Braintreella rogersi prevents they from coming to a firm conclusion.

Stratigraphic and geographic distribution. The age of Badulesia genus is lower Caesaraugustan to the base the middle Cesaraugusta in the Mediterranean Subprovince. It is Eccaparadoxides eteminicus zone in Avalonian Subprovince (Chirivella Matorell et al., 2003) 
and from the Parasolenopleura tenera Zone to the base of the Paradoxides hicksii Zones in St. Mary's Bay, Newfoundland (Fletcher, 2006). It is equivalent to the uppermost Wuliuan to lower Drumian (Miaolingian Series).

Badulesia granieri (Thoral, 1935)

(Fig. 10)

1997. Badulesia granieri (Thoral, 1935); Álvaro \& Vizcaïno, 546 (with previous synonymy).

v 1999. Badulesia granieri (Thoral, 1935); Álvaro et al., fig. 5.E.

2001. Badulesia granieri (Thoral, 1935); Álvaro \& Vizcaïno, pl. 1, fig. 2.

v 2008. Badulesia granieri; Gozalo et al., pl. 3, fig. 5.

v 2015. Badulesia granieri; Palacios, pl. 16, fig. 1.

Material and locality. 15 specimens with cephalon joined to several thoracic segments, the most complete with 16 thoracic segments, one isolated cephalon, over 300 cranidia, 2 librigena and one pygidium. All of them preserved as external and internal moulds in red, blue and yellow dolestones and lutites; from Mansilla Formation to the base of Murero Formation (Iberian Chains). The specimens revisited herein are housed under references MPZ 3066 to MPZ 3076, MPZ 7878 and MPZ 17010 to MPZ 17013, and the new material that have not published previously are MPZ 2007/1107 to MPZ 2007/1170 and MPZ 2019/1062 to MPZ 2019/1064.

Remarks. Badulesia granieri was described previously by Sdzuy $(1961,1968)$ and Courtessole (1973). B. granieri shows a glabella with four transversal ridges with a symmetrical arrangement. The thorax shows 15 thoracic segments. Each pleura has a moderately deep pleural furrow and a paddle-like lappet. The segments bear ornamentation and the axial rings show spines.

Occurrence. This species has been recorded in France (Thoral, 1935; Courtessole, 1973; Álvaro \& Vizcaïno, 2000), Spain (Sdzuy, 1961, 1968, 1969; Liñán \& Gozalo, 1986; Gozalo et al., 1993; Liñán et al., 1995b; Palacios, 2015), and Morocco (Geyer et al., 1995; Geyer \& Landing, 2006b). All of them in the Badulesia granieri and base of Pardailhania hispida Zones (lower and low middle Caesaraugustan; Drumian).

Badulesia paschi (Sdzuy, 1958)

(Fig. 11)

v 1968. Badulesia paschi (Sdzuy, 1961); Sdzuy, 114115 , pl. 8, figs. 3-5 (with previous synonymy).

v 1986. Badulesia paschi (Sdzuy, 1958); Liñán \& Gozalo, 61-62, pl. 23, fig. 9. v 1991. Badulesia paschi (Sdzuy, 1958); Gámez et al., pl. I, fig. 6.

v 1999. Badulesia paschi; Álvaro et al., fig. 5.I.

v 2001. Badulesia paschi (Sdzuy, 1958); Álvaro \& Vizcaïno, pl. 1, fig. 3.

Material and locality. 5 cephalons joined to 15 or less thoracic segments, 20 cranidia, one of them joined to thirteen thoracic segments and one free librigena as internal and external moulds in green and light red lutites and beige dolostones. The specimens revisited herein are housed under references MPZ 3065, MPZ 7854 and MPZ 17006 to MPZ 17008, and the new material that have not published previously are MPZ 2007/1171 to MPZ 2007/1182, MPZ 2007/1185 and MPZ 2019/1058 to MPZ 2019/1061.

Remarks. For a detail description of this species see Sdzuy $(1961,1968)$. B. paschi shows a librigena with another ridge between the ocular crest and the posterior ridge. B. paschi only has been found in Northern Spain.

Occurrence. This species shows a narrow stratigraphic distribution in the base of Pardailhania hispida Zone (Middle Caesaraugustan; Drumian).

Badulesia tenera (Hartt in Dawson, 1868)

(Fig. 12)

v 2003. Badulesia tenera (Hartt in Dawson, 1868); Chirivella Martorell et al., 89-99, figs. 3, 4 (with previous synonymy).

2005. Parasolenopleura tenera (Hartt, in Dawson 1868); Fletcher, text-fig. 5.M, 5.P, 5.Q.

p 2005. Parasolenopleura ouangondiana (Hartt, in Dawson, 1868); Fletcher, text-fig. 5.N.

2006b. Badulesia tenera (Hartt, 1868); Geyer \& Landing, fig. 39.

v 2008. Badulesia tenera; Gozalo et al., pl. 3, fig. 2.

2010. Badulesia tenera Sdzuy 1968 [sic]; Elicki \& Geyer in Heuse et al., fig. 3.21.

v 2011a. Badulesia tenera (Hartt in Dawson, 1868); Gozalo et al., 77-78, figs. 4.D, 4.E, 5.

Material. A complete specimen, over 200 cranidia, nine cephala and one exuvium with five thoracic segments. All of them preserved as internal and external moulds in green and red lutites and beige dolostones. The specimens revisited herein are housed under references MPZ 3063, MPZ 3064, MPZ 7850, MPZ 17003 to MPZ 17005, MPZ 2001/131 to MPZ 2001/192 and MPZ 2001/198, and the 

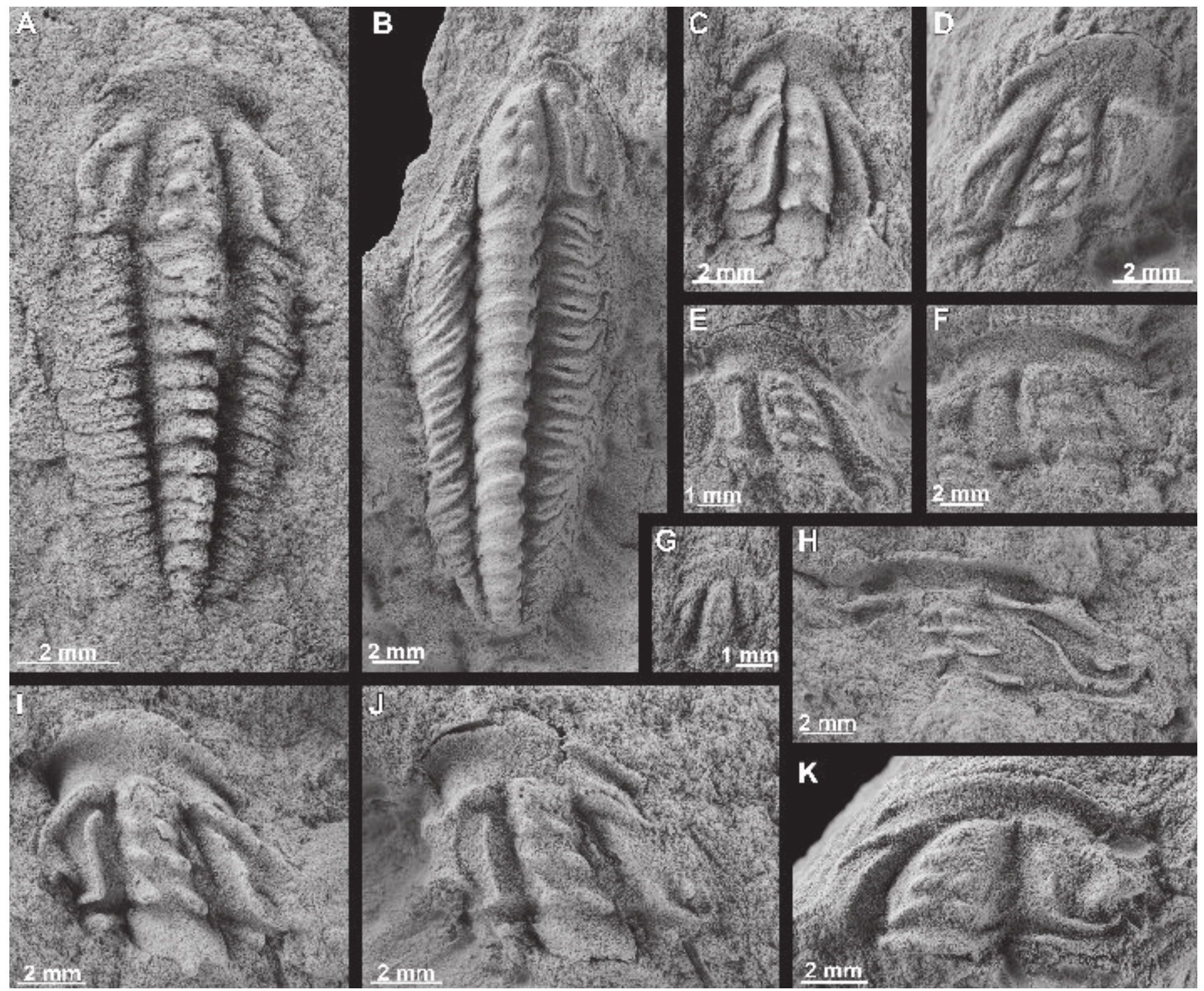

Figure 10. Badulesia granieri (Thoral, 1935). a) Cranidium and 13 thoracic segments, internal mould, Murero Formation, Rambla de Valdemiedes 2 section, MPZ 2019/1062. b) Cephalon and 17 thoracic segmens, internal mould, Murero Formation, Rambla de Valdemiedes 2 Section, MPZ 3070. c) Cranidium, internal mould, Murero Formation, Rambla de Valdemiedes 2 Section, MPZ 3069. d) Cranidium, internal mould, Murero Formation, Rambla de Valdemiedes 2 Section, MPZ 3075. e) Cranidium, internal mould, Murero Formation, Rambla de Valdemiedes 2 Section, MPZ 3073. f) Cranidium, internal mould, Murero Formation, Rambla de Valdemiedes 2 Section, MPZ 3074. g) Cranidium, internal mould, Murero Formation, Rambla de Valdemiedes 1 Section, MPZ 3067. h) Cranidium, internal mould, Murero Formation, Rambla de Valdemiedes 2 Section, MPZ 3071. i-j) Cranidium, latex cast and internal mould of the same specimen, Murero Formation, Rambla de Valdemiedes 2 Section, MPZ 3066 and MPZ 3068. k) Cranidium, internal mould, Murero Formation, Rambla de Valdemiedes 1 Section, MPZ2007/141.

new material that have not published previously are MPZ 2007/193, MPZ 2007/1104 to MPZ 2007/1106, MPZ 2007/1393, MPZ 2007/1445 and MPZ 2019/1050 to MPZ 2019/1057.

Remarks. Chirivella Martorell et al. (2003) studied Badulesia tenera biometrically and emended the genus Badulesia diagnosis. Fletcher (2005) proposed the inclusion of $B$. tenera in genus Parasolenopleura due its strong similarity. Nevertheless, we consider $B$. tenera as a Badulesia species since Parasolenopleura does not present the typical structures of the genus Badulesia such as at least a pair of internal ridges in the fixigena, together with the ridge formed by the palpebral lobes and ocular ridge union, this being a defining characteristic of the genus Badulesia (see Chirivella Martorell et al., 2003). 

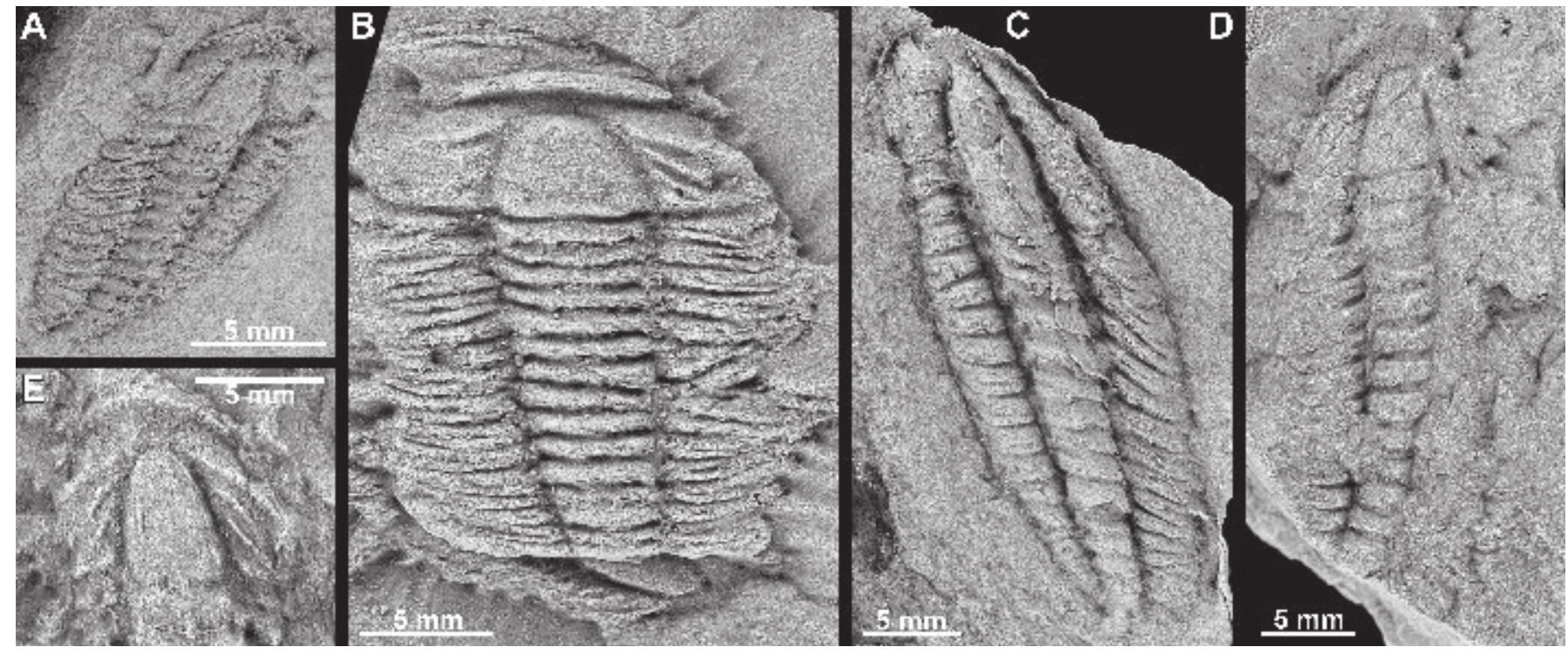

Figure 11. Badulesia paschi (Sdzuy, 1958). a) Cranidium and 13 thoracic segments, internal mould, Murero Formation, Rambla de Valdemiedes 1 Section, MPZ2007/1185. b) Cranidium and 14 thoracic segments, internal mould, Murero Formation, Rambla de Valdemiedes 1 Section, MPZ17008. c) Cranidium and 15 thoracic segments, internal mould, Murero Formation, Rambla de Valdemiedes 1 Section, MPZ 3065. d) Cranidium and 13 thoracic segments, internal mould, Murero Formation, Villafeliche 1 Section, MPZ2007/1178. e) Cranidium, internal mould, Murero Formation, Rambla de Valdemiedes 1 Section, MPZ2007/1183.

Occurrence. See Chirivella Martorell et al. (2003), later to this work, this specie has been found in the Rambla de Valdemiedes 1 and Villafeliche 1 sections. Also, it has been found in the Purujosa area (Jorge Esteve, 2011, personal communication). Its biostratigraphic distribution goes from the $B$. tenera Zone to the base of the $P$. hispida Zone in the Iberian Chains. Fletcher (2006) also described a wide distribution of this species in St. Mary's Bay (Newfoundland) ranging between Parasolenopleura tenera Zone and the base of Paradoxides hicksii Zone; uppermost Wuliuan-Drumian in age.

\section{Genus Pardailhania Thoral, 1947}

Type species Solenopleura? hispida Thoral 1935, by original designation Thoral $(1947 ; 60)$.

Remarks. Thoral (1948; 56-60) described Pardailhania and considered the number of tubercles in the preglabellar field as a diagnostic character. This author distinguished between $P$. hispida (with one row) and $P$. multispinosa (with two rows). Sdzuy $(1958 ; 241)$ defined $P$. hispanica also with two rows in the pregabellar field. Sdzuy (1958, 1961) differentiated P. multispinosa of $P$. hispanica by the size and density of the spiny tubercles. Courtessole (1973) revisited the French species and described new material that revealed the morphological variability range in P. hispida and P. multispinosa. Also, he described and figured one specimen of $P$. multispinosa with three rows of tubercles in the preglabellar field.
Afterwards, Liñán \& Gozalo (1986; 62-64) recognized four Pardailhania species in Murero (hispida, hispanica, multispinosa and sdzuyi); they indicated that a revision of $P$. hispanica and P. multispinosa was necessary, but maintained the species defined by Sdzuy (1958) and defined P. sdzuyi Liñán \& Gozalo, 1986 with three spiny tubercles rows in the pregabellar field and seven or eight rows on the glabella. Álvaro (1996) defined a new species, P. morisca that characterised by the presence of three spiny tubercles rows in the preglabellar field and four to six in the glabella. Álvaro \& Vizcaïno (1997; 546-548) emended the definitions of $P$. hispida and P. multispinosa. For this species proposed as main character the presence of two spiny tubercles rows in the preglabellar field.

More than 500 cranidia of Pardailhania have been collected in stratigraphic order in the Iberian Chains sections. The studied specimens show three main evolutive trends in the cranidia ornamentation that have been previously commented on Sdzuy $(1961,1968)$, Courtessole (1973), Liñán \& Gozalo (1986) and Álvaro \& Vizcaïno (2001): 1) the number of spiny tubercles rows on the preglabellar area increases from one to three; 2 ) the number of spiny tubercles rows in the glabella (without occipital ring) in the earlier forms is four or five while in the modern forms up to nine rows. It is observed that the number of spiny tubercles increases from the earliest forms to modern forms; 3 ) the number of spiny tubercles rows in the occipital ring is one for the earlier forms and two for the modern. 

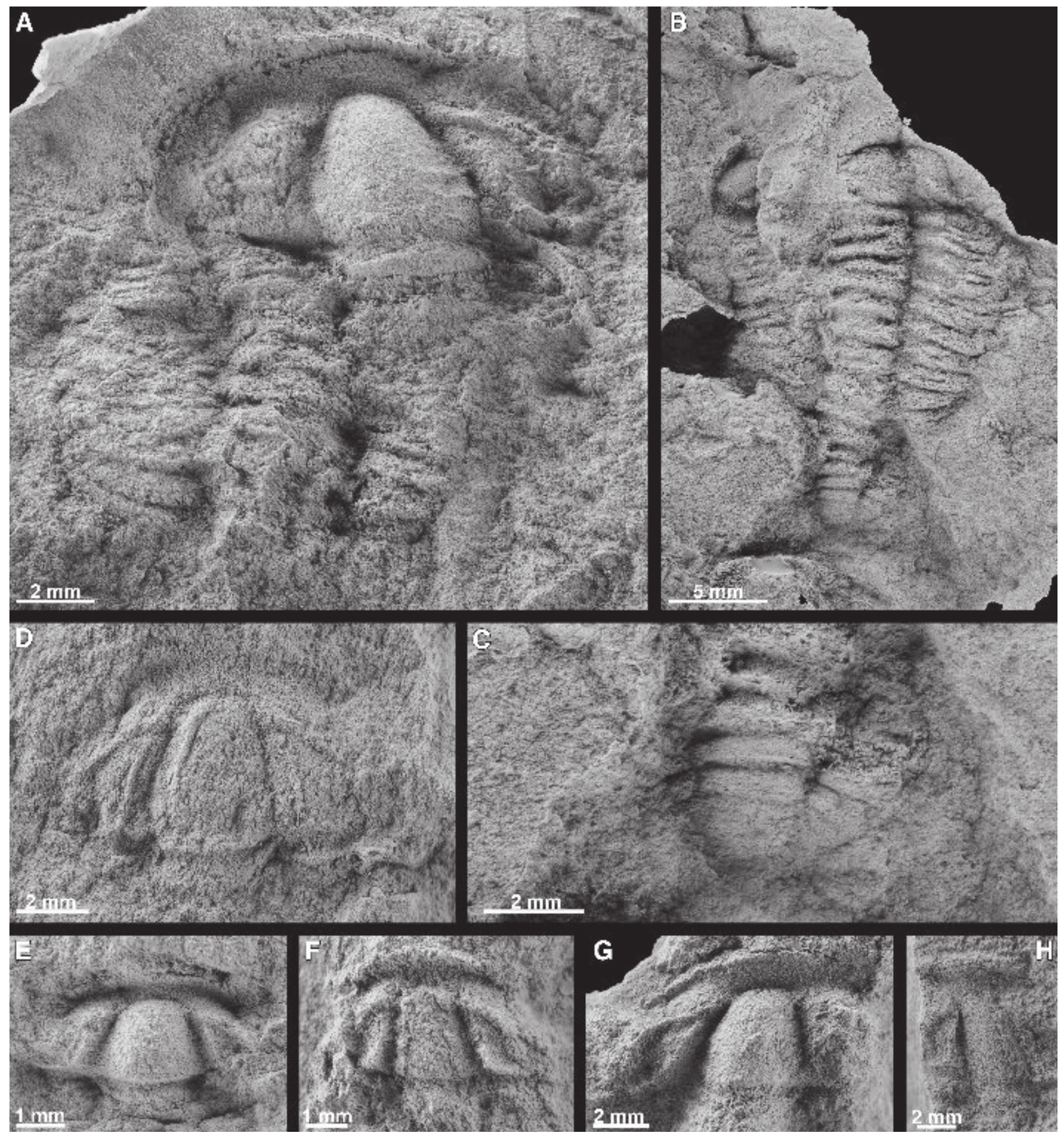

Figure 12. Badulesia tenera (Hartt in Dawson, 1868). a) Exuvia, cephalon and 8 thoracic segments, latex cast, morphotype A, Mansilla Formation, Jarque 1 section, MPZ2001/142. b-c) Bad preserved specimen, with cephalon, thorax and pygidium, Mansilla Formation, Jarque 1 section, MPZ 2019/1050; c, close-up of the pygidium. d) Cranidium, latex cast, morphotype B, Mansilla Formation, Jarque 1 section, MPZ2001/182. e) Cranidium, latex cast, morphotype A, Mansilla Formation, Jarque 1 section, MPZ2001/138. f) Cranidium, internal mould, morphotype A, Mansilla Formation, Jarque 1 section, MPZ2001/173. g) Cranidium, internal mould, morphotype A, Mansilla Formation, Jarque 1 section, MPZ2001/163. h) Cranidium, internal mould, morphotype B, Mansilla Formation, Rambla de Valdemiedes 1 section, MPZ2007/1445. 
In accordance with the different works published we keep four species of the genus Pardailhania: P. hispida, $P$. multispinosa ( $P$. hispanica is a junior subjective synonym), $P$. morisca (including the material classified as P. multispinosa by Liñán \& Gozalo 1986) and $P$. sdzuyi.

\section{Pardailhania hispida (Thoral, 1935)}

(Fig. 13)

v 1995. Pardailhania hispida (Thoral, 1935); Loi et al., pl. 4, fig. 3 .

v 1997. Pardailhania hispida (Thoral, 1935); Álvaro \& Vizcaïno, 546-548, fig. 3 1-4 (with previous synonymy).

v 2001. Pardailhania hispida (Thoral, 1935); Álvaro \& Vizcaïno, 133, pl. 1, fig. 4.

v 2001. Pardailhania hispida (Thoral, 1935); Álvaro et al., 230, pl. XV, fig. 3.

2005. Pardailhania hispida (Thoral, 1935); Dean, 4041, pl. 9 (a), (b), (g), (h).

2006. Pardailhania hispida (Thoral, 1935); Dean, 237238, pl. 1 (f), (g), (i), (k), (q).

v 2008. Pardailhania hispida; Gozalo et al., pl. 3, fig. 4. v 2010. Pardailhania cf. hispida (Thoral, 1935); Esteve et al., fig. 6.A.

v 2011b. Pardailhania hispida (Thoral, 1935); Gozalo et al., fig. 6.M.

v 2013. Pardailhania cf. hispida (Thoral, 1935); Esteve, fig. 4.B.

Material and locality. 60 cranidia and four cephala with several thoracic segments preserved as external and internal moulds in grey, green and yellow lutites from Murero Formation (Iberian Chains). The specimens revisited herein are housed under references MPZ 3077 to MPZ 3082, MPZ 17017 and MPZ 17018, and the new material that have not published previously are MPZ 2007/1187 to MPZ 2007/1215, MPZ 2008/113, MPZ 2008/116 and MPZ 2008/117.

Remarks. For a good description of Pardailhania hispida see Courtessole (1973). Sdzuy (1968) classified the oldest specimens of $P$. hispida as Pardailhania hispida n. ssp. because it presented some morphological similarities with Badulesia granieri as the spines in the fixigena and in the ridges of the glabella located in a shallow ridge, different from the more modern Pardailhania. However, he never published a description and definition of this subspecies.

The new material, recorded at successive levels in the different sections of the Iberian Chains, shows a wide and continuous morphological variation in the cranidia, without observing morphological characters sufficiently different to separate these populations into different taxa. Thus, we accept that Pardailhania hispida has a wide and continuous morphological variation within the features of cranidia (Chirivella Martorell, 2008; Esteve et al., 2008), and that it is not possible to recognise two subspecies, as Sdzuy had proposed.

Occurrence. Pardaihania hispida and P. multispinosa Zones (middle Cesaraugusta; Drumian) (Liñán et al., 1993; Álvaro \& Vizcaïno, 1998; Gozalo et al., 2011b).

\section{Pardailhania multispinosa Thoral, 1948}

(Fig. 14)

* 1948. Pardailhania multispinosa nov. sp.; Thoral, 55-57, pl III, figs. 8-9.

v 1958. Pardailhania hispanica nov sp.; Sdzuy, 120, pl.8, fig. 6.

v 1961. Pardailhania hispanica Sdzuy, 1958; Sdzuy, 634-636, pl. 25, fig. 5-12.

1961. Pardailhania hispida (Thoral); Dean \& Krummenacher, pl. 10, fig. 3.

v 1968. Pardailhania hispanica Sdzuy, 1958; Sdzuy, 120 , pl. 8, fig. 6 .

p 1973. Pardailhania multispinosa Thoral, 1948; Courtessole, 163-165, pl. XV, figs. 9-13, 15-18.

n 1973. Pardailhania multispinosa Thoral, 1948; Courtessole, pl. XV, fig. 14.

v 1986. Pardailhania hispanica Sdzuy, 1958; Liñán \& Gozalo, 63, pl. 25, figs. 2-10.

v 1993. Pardailhania hispanica Sdzuy, 1958; Gozalo et al., 56, pl. I, fig. 9.

v 1997. Pardailhania multispinosa Thoral 1948; Álvaro \& Vizcaïno, 548, fig. 3.4-5.

v 2001. Pardailhania multispinosa (Thoral 1948); Álvaro \& Vicaïno, 133, pl. 1, fig. 5-6.

?v 2001. Pardailhania cf. hispanica; Liñán \& Sdzuy, 258-260, fig. 7a-c.

v 2010. Pardailhania multispinosa Thoral, 1948; Esteve et al., fig. 7.A-B.

v 2013. Pardailhania multispinosa; Esteve, fig. 2. B.

Material and locality. 100 cranidia and 15 cephala with several thoracic segments preserved as external and internal moulds in grey, green and yellow lutites from Murero Formation (Iberian Chains). The specimens 


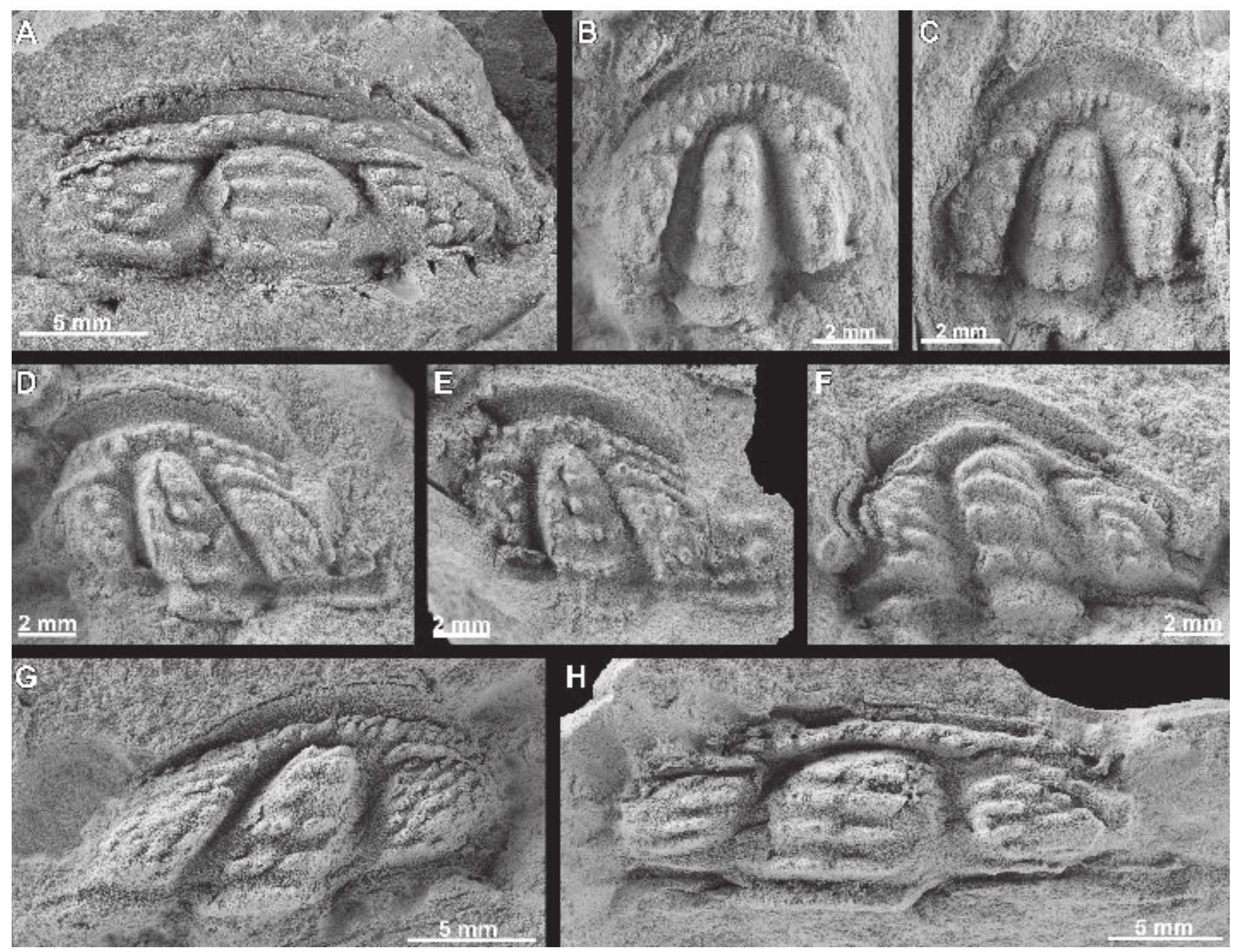

Figure 13. Pardailhania hispida (Thoral, 1935). a) Cranidium, internal mould, Murero Formation, Rambla de Valdemiedes 2 section, MPZ2007/1194. b-c) Cranidium, internal mould and latex cast of the same specimen, Murero Formation, Rambla de Valdemiedes 2 section, MPZ 3078. d-e) Cranidium, internal mould and latex cast of the same specimen, Murero Formation, Rambla de Valdemiedes 2 section, MPZ 3079. f) Cranidium, internal mould, Murero Formation, Rambla de Valdemiedes 2 section, MPZ 3077. g) Cranidium, internal mould, Murero Formation, Rambla de Valdemiedes 1 section, MPZ 3082. h) Cranidium, internal mould, Murero Formation, Rambla de Valdemiedes 1 section, MPZ 3080.

revisited herein are housed under references MPZ 3083 to MPZ 3091, MPZ 7879 and MPZ 17019 to MPZ 17021, and the new material that have not published previously are MPZ 2008/114, MPZ 2008/170 and MPZ 2019/1066.

Remarks. For a good description see Courtessole (1973). We agree with the proposal of Álvaro \& Vizcaïno (1997) who includes all the Pardailhania specimens with two spiny tubercles in the preglabellar field multispinosa. Thus, $P$. hispanica is a junior subjective synonym of $P$. multisipinosa.

Occurrence. Pardailhania multispinosa Zone to base of the Solenopleuropsis ribeiroi Zone (middle Caesaraugustan; Drumian).
Pardailhania morisca Álvaro, 1996

(Fig. 15)

p 1973. Pardailhania multispinosa Thoral, 1948; Courtessole, pl. XV, fig. 14.

v 1986. Pardailhania multispinosa Thoral, 1948; Liñán \& Gozalo, pl. 25, fig. 11, pl. 26 figs. 1-2.

v* 1996. Pardailhania morisca n. sp.; Álvaro, 77, pl. 3 , fig. 1.

v 1997. Pardailhania morisca Álvaro, 1996; Álvaro \& Vicaïno, 548, fig. 3.6. 


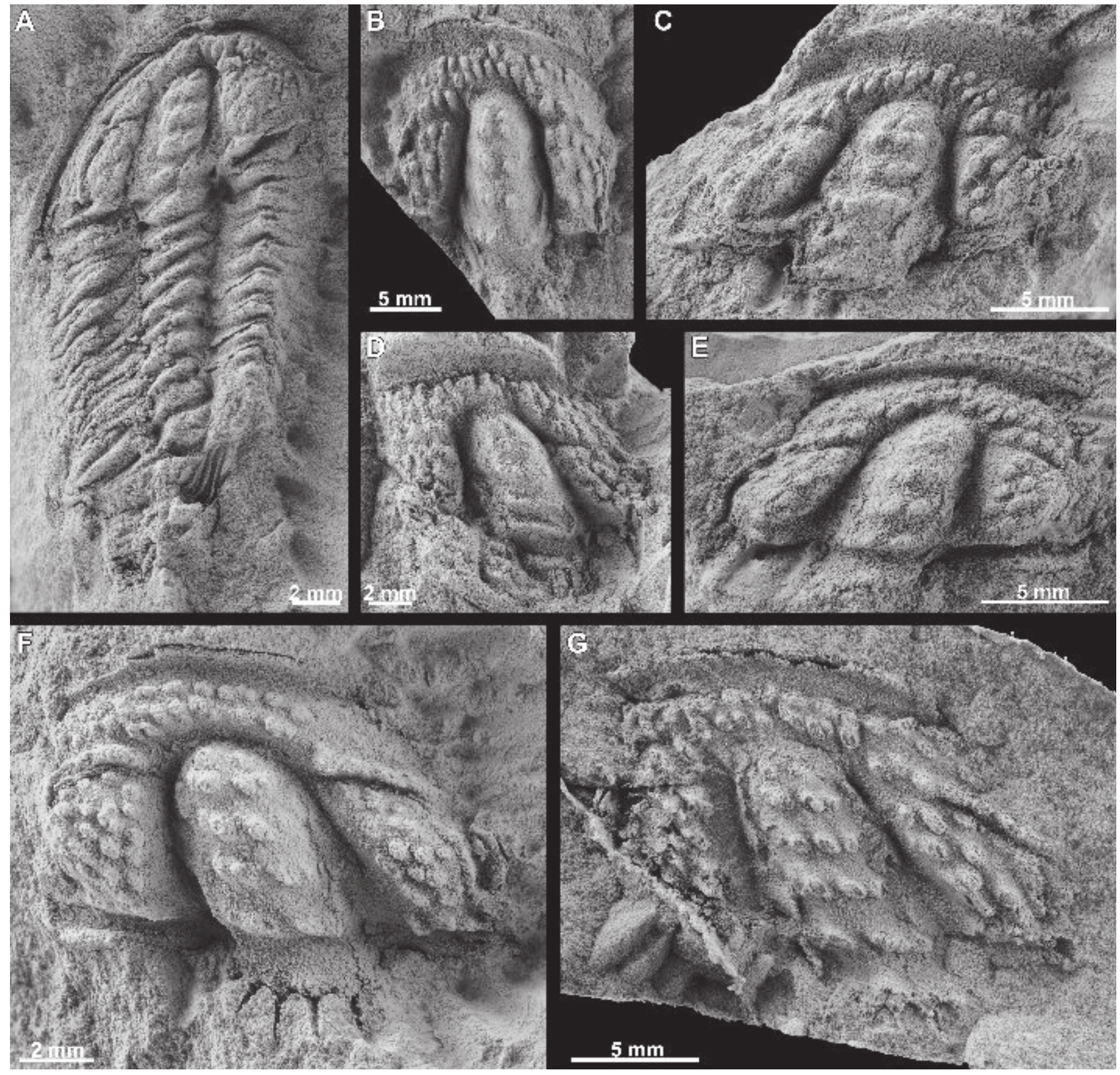

Figure 14. Pardailhania multispinosa Thoral, 1948. a) Cepahlon with 9 thoracic segments, internal mould, Murero Formation, Rambla de Valdemiedes 2 section, MPZ 3089. b) Cranidium, internal mould, Murero Formation, Rambla de Valdemiedes 2 section, MPZ 3085. c) Cranidium, internal mould, Murero Formation, Rambla de Valdemiedes 2 section, MPZ 3083. d) Cranidium, internal mould, Murero Formation, Rambla de Valdemiedes 1 section, MPZ 3087. e) Cranidium, internal mould, Murero Formation, Rambla de Valdemiedes 2 section, MPZ 3084. f) Cranidium, internal mould, Murero Formation, Rambla de Valdemiedes 1 section, MPZ 3091. g) Cranidium, latex cast, Murero Formation, Rambla de Valdemiedes 1 section, MPZ 3088.

Material and locality. 20 cranidia preserved as external and internal moulds in grey, green and yellow lutites from Murero Formation (Iberian Chains). The specimens revisited herein are housed under references MPZ 3092 to MPZ 3096, MPZ 17022 and 17023.
Remarks. For a good description of Pardailhania morisca see Álvaro (1996).

Occurrence. Upper part of the Pardailhania multispinosa Zone to base of the Solenopleuropsis ribeiroi Zone (middle Caesaraugustan; Drumian). 
Pardailhania sdzuyi Liñán \& Gozalo, 1986

(Fig. 16)

v 1957. (Zwischenform von Solenopleuropsis und Pardailhania); Sdzuy, 25.

v 1961. Solenopleuropsis n. sp.; Sdzuy, 641-643, pl. 24, fig. 13.

? 1964. Conocoryphe sulzeri Schloth; Meléndez \& Asensio Amor, 9-10, pl. II, fig C.

v* 1986. Pardailhania sdzuyi n. sp.; Liñán \& Gozalo, 64-65, pl. 26, figs. 4-11.

v 1997. Pardailhania sdzuyi Liñán \& Gozalo, 1986; Álvaro \& Vicaïno, 548-549, fig. 3.7.

v 1999. Pardailhania sdzuyi; Sender et al., 345-347. pl. 1, fig. 1 .

? 2005 Pardailhania sp.; Dean, 41, pl. 9, fig. c.

Diagnosis (as in Liñán \& Gozalo, 1986; 64). Species of Pardailhania with three rows of spiny tubercles in the preglabelar field, between seven to eight rows in the glabella and two rows of spines in the occipital ring.

Material and locality. At least 150 cranidia and 10 cephala, some of them with four or five thoracic segments as external and internal moulds in grey, green and yellow lutites from Murero Formation (Iberian Chains). The specimens revisited herein are housed under references MPZ 3097 to MPZ 3104, MPZ 9965, MPZ 9966, MPZ 17024 and 17025, and the new material that have not published previously are MPZ 2019/1067 to MPZ 2019/1069.

Remarks. For a good description of Pardailhania sdzuyi see Liñán \& Gozalo (1986). Pardailhania sdzuyi bears three rows of spines in the preglabellar field as $P$. morisca, but the number of rows in the glabella is bigger in P. sdzuyi.

Occurrence. Uppermost Pardailhania multispinosa Zone and Solenopleuropsis ribeiroi Zone (middle and lower upper Caesaragustan; Drumian).

\section{BIOSTRATIGRAPHY}

The trilobite zonation for mid middle Cambrian in the Iberian Peninsula and France has been classically established using Solenopleuropsinae species (Sdzuy, 1968, 1971, 1972; Liñán \& Gozalo, 1986; Liñán et al., 1993, 2002; Álvaro \& Vizcaïno, 1998).

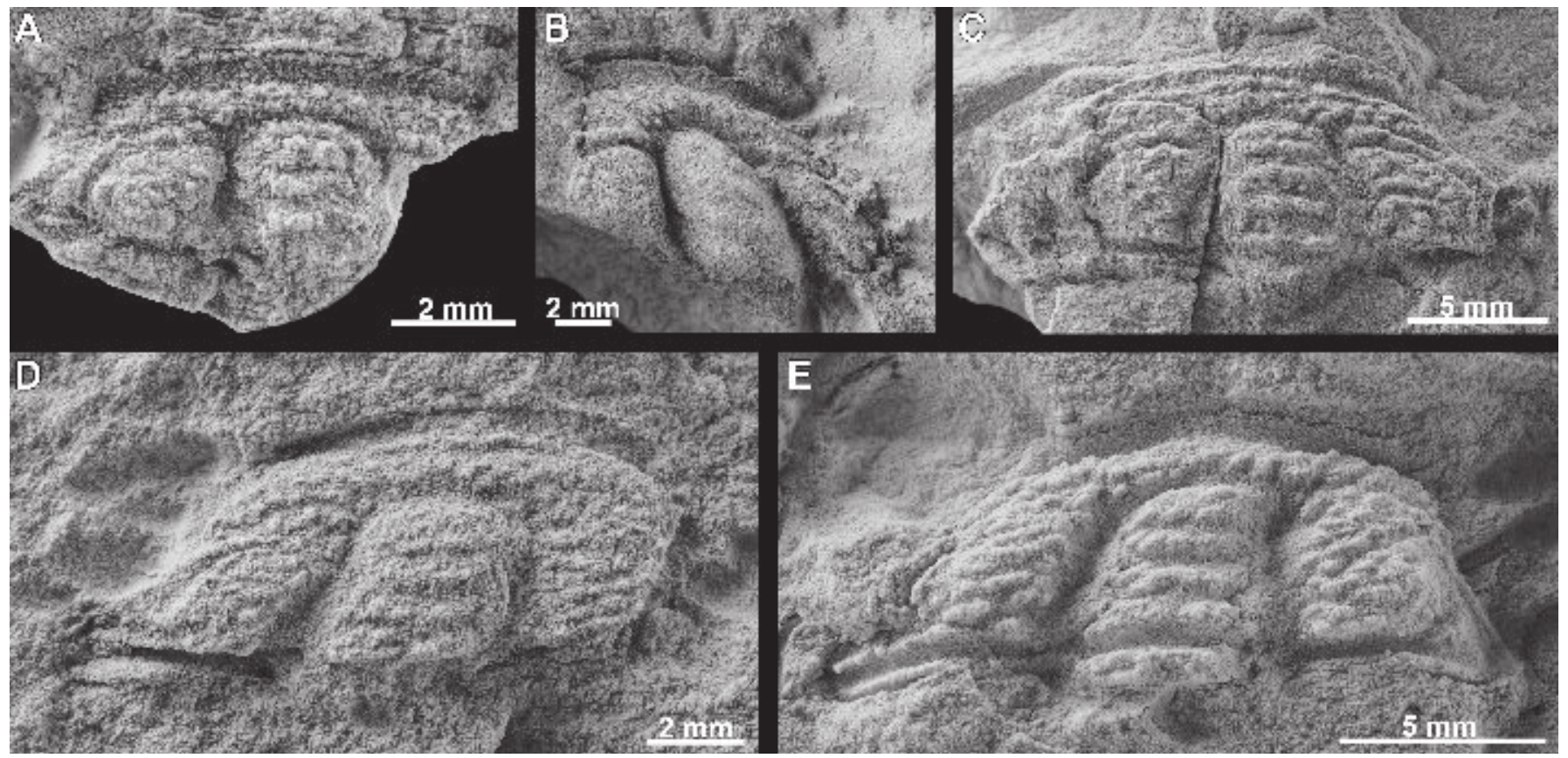

Figure 15. Pardailhania morisca Álvaro, 1996. a) Cranidium, latex cast, Murero Formation, Rambla de Valdemiedes 1 section, MPZ 3096. b) Cranidium, internal mould, Murero Formation, Rambla de Valdemiedes 1 section, MPZ 3094. c) Cranidium, internal mould, Murero Formation, Rambla de Valdemiedes 1 section, MPZ 3092. d) Cranidium, internal mould, Murero Formation, Rambla de Valdemiedes 2 section, MPZ 3095. e) Cranidium, internal mould, Murero Formation, Rambla de Valdemiedes 2 section, MPZ 3093. 

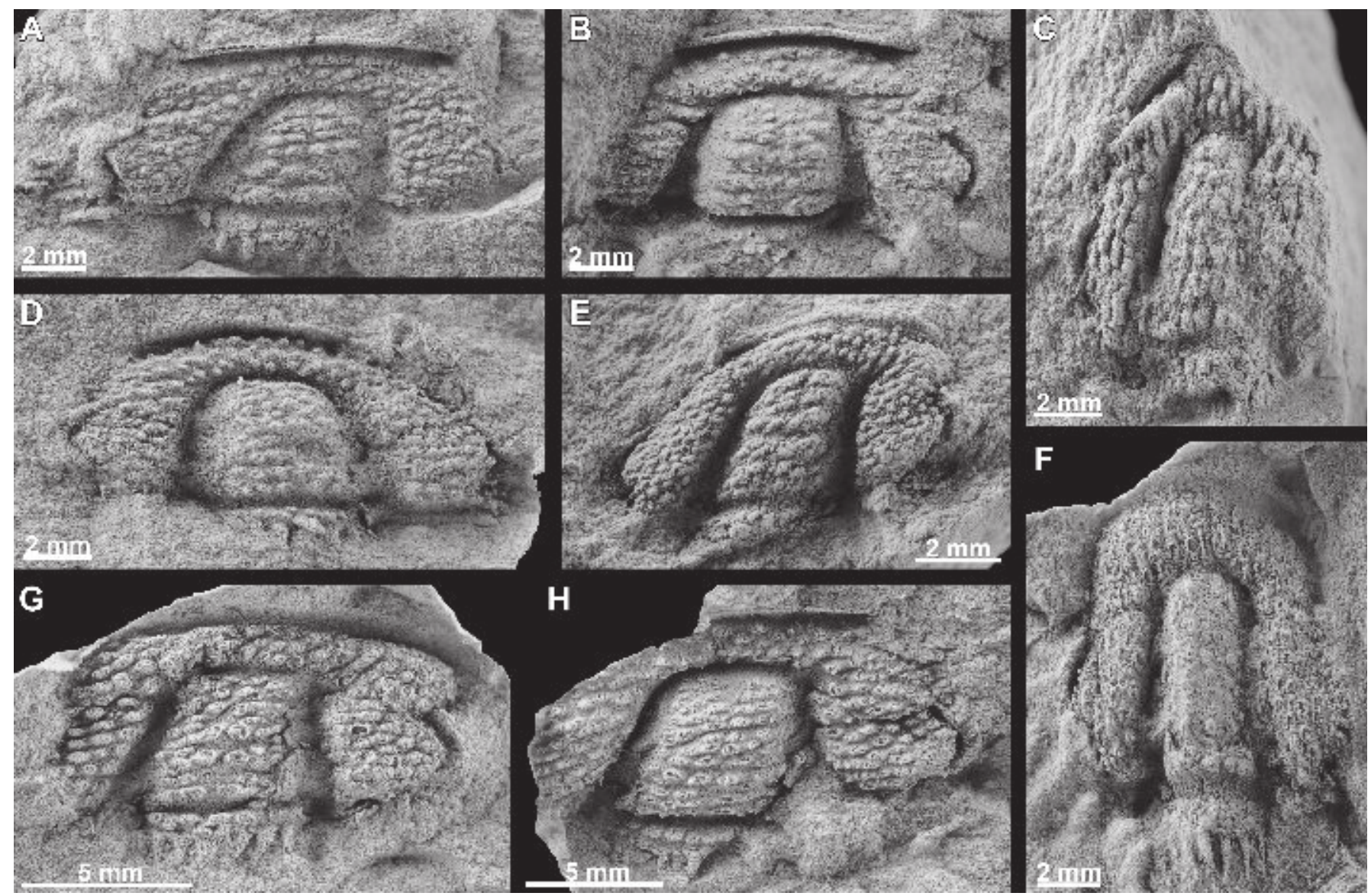

Figure 16. Pardailhania sdzuyi Liñán \& Gozalo, 1986. a) Cranidium, latex cast, Murero Formation, Rambla de Valdemiedes 2 section, MPZ 3100. b) Cranidium, latex cast, Murero Formation, Rambla de Valdemiedes 1 section, MPZ 3103. c) Cranidium, internal mould, Murero Formation, Rambla de Valdemiedes 2 section, MPZ 3102. d) Cranidium, latex cast, Murero Formation, Rambla de Valdemiedes 1 section, MPZ 3099. e) Cranidium, internal mould, Murero Formation, Rambla de Valdemiedes 2 section, MPZ 3101. f) Cranidium, latex cast, Murero Formation, Rambla de Valdemiedes 2 section, MPZ 3098. g) Cranidium, latex cast, Murero Formation, Rambla de Valdemiedes 2 section, MPZ 3104, Holotype. h) Cranidium, latex cast, Murero Formation, Rambla de Valdemiedes 1 section, MPZ 3097.

However, the concepts of the different zones and biozones used in those previous works do not coincide in all. Thus, the detailed revision for the distribution of genera Badulesia and Pardailhania accomplished herein, allow us to propose a more accurate stratigrafic range for the species of both genera in the Iberian Chains completing the work published by Gozalo et al. (2011b).

As shown in Figure 1 (Gozalo et al., 2011b, and our proposal), the phylozones for the lower and middle Caesaraugustan will be Badulesia tenera, Badulesia granieri, Pardailhania hispida and Pardailhania multispinosa; in accordance with the tentative evolutionary lineage proposed for this group (see Sdzuy, 1968; Álvaro \& Vizcaïno, 2001) (Fig. 7). Furthermore, the detailed analysis of the stratigraphic distribution of the trilobite species in this time interval (Fig. 3) allow us to redefine the zonation for the lower and middle Caesaraugustan (Miaolingian Series) in the Iberian Chains, which is applicable in the Mediterranean region. However, all the index species have been recorded in France and Spain, while in other areas of the Mediterranean Subprovince only some of the index taxa have been recorded. For this reason we define two superzones: Badulesia and Pardailhania, that have previously used as informal units.

The Badulesia superzone is equivalent to the early Caesaraugustan and, the Pardailhania superzone, to the middle Caesaraugustan. Both superzones have been used as biozones in Turkey (Dean \& Monod, 1997; Dean, 2005, 2006), substages in Sardinia (Loi et al., 1995) and zones in Morocco (Geyer et al., 1995; Geyer \& Landing, 2004, 2006a, 2006b).

\section{Badulesia Superzone}

Synonymy. Badulesia Stage (Sdzuy, 1968). Badulesia substage (Sdzuy, 1971, 1972; Liñán \& Gozalo, 1986; Loi et al., 1995). Badulesia Biozone (Dean \& Monod, 1997; Dean, 
2005, 2006). Badulesia tenera zone sensu Geyer \& Landing (2004). Badulesia Zone (Geyer \& Landing, 2006a).

Badulesia Superzone is composed of B. tenera and $B$. granieri zones. Its lower boundary is placed at the FAD of Badulesia tenera and characterizes the lower Caesaraugustan. Its upper boundary is placed in the previous level to Pardailhania hispida FAD.

\section{Badulesia tenera interval zone}

Synonymy. Badulesia tenera level (Sdzuy, 1968, 1971), Badulesia tenera biozone (Liñán \& Gozalo, 1986; Sdzuy et al., 1996), Badulesia tenera Zone (Liñán et al., 2002, 2004, 2008; Gozalo et al., 2008, 2011b; Chirivella-Martorell et al., 2015, 2017). Not the Parasolenopleura tenera Zone (Fletcher, 2006), that would be equivalent to the lower part of Badulesia tenera interval Zone.

Sdzuy (1968) established an informal division named level of Badulesia tenera; Liñán \& Gozalo (1986) characterized this like a taxon acrozone; afterwards, Sdzuy et al. (1996 and posterior works) use this zone like an interval zone. The lower boundary of this zone is placed at the FAD of Badulesia tenera, and its upper boundary is placed in the previous level to Badulesia granieri FAD (Figs 1, 3).

Trilobite assemblage. Peronopsis acadica (Hartt in Dawson, 1868), Condylopyge sp., Badulesia tenera (Hartt in Dawson, 1868), Eccaparadoxides asturianus (Sdzuy, 1968), E. sdzuyi Liñán Guijarro, 1978, E. sulcatus Liñán \& Gozalo, 1986, Hydrocephalus brausei (Sdzuy, 1970), Acadolenus sp., Asturiaspis inopinatus Sdzuy, 1968, Parasolenoplera aculeata (Angelin, 1851), Holocephalina? leve Gozalo \& Liñán, 1996, Parabailiella languedocensis Thoral, 1946, P. matutina Sdzuy, 1968, P. sebarensis Sdzuy, 1968, P. schmidti Sdzuy, 1957, Ctenocephalus cf. terranovicus (Resser, 1937), Bailiaspis cf. tuberculata Lake, 1940, Bailiaspis sp. and Bailiella cf. tenuicincta (Linnarsson, 1879); in addition, Agraulos cf. arenosus Sdzuy, 1968, Ellipsocephalus bernardi Liñán Guijarro, 1978 and Eccaparadoxides cf. pusillus (Barrande 1846) are also in Sierra Morena.

Badulesia tenera is widely distributed along the Mediteranean subprovince and the eastern coast of North America (Chirivella Matorell et al., 2003). It allows a correlation with the Ptychagnostus gibbus zone (Sdzuy et al., 1999; Gozalo et al., 2007). New data of acritarchs (Palacios, 2015) indicates that the lower part of Badulesia tenera zone correlates with the upper part of the Ptychagnostus gibbus zone.

\section{Badulesia granieri interval zone}

Synonymy. Gozalo et al. (2011b) revisited this interval zone, and we follow the same concept. Its base coincides with the FAD of Badulesia granieri and the top is the previous level to the Pardailhania hispida FAD.
Trilobite assemblage. Peronopsis acadica (Hartt in Dawson, 1868), Condylopyge sp., Eccaparadoxides asturianus (Sdzuy, 1968), E. sulcatus Liñán \& Gozalo, 1986, E. sequeirosi Liñán \& Gozalo, 1986, E. acadicus (Matthew, 1883), Badulesia granieri (Thoral, 1935), B. tenera (Hartt in Dawson, 1868), Parabailiella schmidti Sdzuy, 1957, P. languedocensis Thoral, 1946, Bailiella cf. tenuicincta (Linnarsson, 1879), and Ctenocephalus $\mathrm{cf}$. terranovicus (Resser, 1937); in addition, Dolichometopus sp., Parasolenopleura aculeata (Angelin, 1851), and Eccaradoxides cf. pusillus (Barrande, 1846) are also recorded in Sierra Morena.

Badulesia granieri has been recorded in Montagne Noire, France (Courtessole, 1973; Álvaro \& Vizcaïno, 1997, 1998), Spain (Sdzuy, 1961, 1968, 1969; Liñán \& Gozalo, 1986; Gámez et al., 1991; Gozalo et al., 1993; Liñán et al., 1995b; Palacios, 2015), and Morocco (Geyer et al., 1995; Geyer \& Landing, 2006b). Furthermore, it could be possible to recognise equivalent levels to this zone in Turkey and Italy, where index taxa from previous and/or posterior zones have been identified (Dean \& Krummenacher, 1961; Rasetti, 1972; Shergold \& Sdzuy, 1984; Dean et al., 1986; Loi et al., 1995; Dean, 2005, 2006).

\section{Pardailhania Superzone}

Synonymy. Pardailhania Stage (Sdzuy, 1968; Dean \& Özgül, 1981). Pardailhania substage (Sdzuy, 1971, 1972; Liñán \& Gozalo, 1986; Loi et al., 1995). Pardailhania Biozone (Dean \& Monod, 1997; Dean, 2005, 2006; Ghienne et al., 2010). Pardailhania Zone (Geyer \& Landing, 2006a).

The Pardailhania Superzone is composed of the $P$. hispida and $P$. multispinosa zones. Its lower boundary is placed at the FAD of Pardailhania hispida and characterizes the middle Caesaraugustan. Its upper boundary is placed in the previous level to Solenopleuropsis ribeiroi FAD.

\section{Pardailhania hispida interval Zone}

Synonymy. Gozalo et al. (2011b) revisited this interval zone, here we use the same concept; which base coincides with the Pardailhania hispida FAD and the top is the level previous to the Pardailhania multispinosa FAD.

Trilobite assemblage. Peronopsis acadica (Hartt in Dawson, 1868), P. segmenta Robison, 1964, Peronopsella westergardi (Sdzuy, 1958), Diplagnostus planicauda (Angelin, 1851), Condylopyge rex (Barrande, 1846), Pardailhania hispida (Thoral, 1935), Badulesia granieri (Thoral, 1935), B. paschi (Sdzuy, 1958), Eccaparadoxides asturianus (Sdzuy, 1968), E. sequeirosi Liñán \& Gozalo, 1986, E. acadicus (Matthew, 1883), E. rouvillei (Miquel, 1905), Parabailiella schmidti Sdzuy, 1957, P. languedocensis Thoral, 1946, Ctenocephalus antiquus Thoral, 1946, Agraulos longicephalus (Hicks, 1872), A. arenosus Sdzuy, 1968, and Skreiaspis miqueli Álvaro \& Vizcaïno, 2000. 
Pardailhania hispida has been recorded in Montagne Noire, France (Thoral, 1935; Courtessole, 1973; Álvaro \& Vizcaïno, 1997), Spain (Sdzuy, 1961, 1968; Palacios, 1982; Liñán \& Gozalo, 1986; Gozalo et al., 2011b), Italy (Rasetti, 1972; Loi et al., 1995), and Turkey (Dean \& Özgül, 1981; Shergold \& Sdzuy, 1984; Dean, 2005, 2006). In addition Geyer et al. (1995) and Geyer \& Landing (2006b) cited the genus Pardailhania in Morocco.

\section{Pardailhania multispinosa interval Zone}

Synonymy. $P$. hispanica and $P$. multispinosa (Sdzuy, 1968, 1971, 1972). Pardailhania hispanica and Pardailhania multispinosa biozones (Liñán \& Gozalo, 1986). P. multispinosa, P. morisca and P. sdzuyi phylozones (Álvaro \& Vizcaïno, 1998). P. multispinosa and P. sdzuyi zones (Esteve et al., 2008; Gozalo et al., 2008).

The concept of Pardailhania multispinosa Zone used herein include the classical two last Pardailhania zones named $P$. hispanica and P. multispinosa by Sdzuy (1968, and posterior works) which is also equivalent to the sum of P. multispinosa, P. morisca and P. sdzuyi sensu Álvaro $\&$ Vizcaino (1998). The base of this zone coincides with the Pardailhania multispinosa FAD and the top is the level previous to the Solenopleuropsis ribeiroi FAD.

Trilobite assemblage. Peronopsis acadica (Hartt in Dawson, 1868), Condylopyge rex (Barrande, 1846), Badulesia tenera (Hartt in Dawson, 1868), Pardailhania hispida (Thoral, 1935), P. multispinosa Thoral, 1948, P. morisca Álvaro, 1996, P. sdzuyi Liñán \& Gozalo, 1986, Eccaparadoxides sequeirosi Liñán \& Gozalo, 1986, E. rouvillei (Miquel, 1905), E. mediterraneus Pompeckj, 1901, Hydrocephalus donayrei Liñán \& Gozalo, 1986, Parabailiella languedocensis Thoral, 1946, Conocoryphe heberti Munier-Chalmas \& Bergeron in Bergeron, 1889, Ctenocephalus antiquus Thoral, 1946, Bailiaspis meridiana Sdzuy, 1958, B. aff. meridiana Sdzuy, 1958, and Agraulos longicephalus (Hicks, 1872).

Pardailhania multispinosa has been recorded in Montagne Noire, France (Thoral, 1935; Courtessole, 1973; Álvaro \& Vizcaïno, 1997), Spain (Sdzuy, 1961, 1968; Palacios, 1982; Liñán \& Gozalo, 1986), and Morocco (Geyer \& Landing, 2006b).

\section{CONCLUSIONS}

The detailed study of nine sections in the Iberian Chains has allowed establishing a precised distribution of the trilobite species recorded in the upper part of the Valdemiedes Fm., Mansilla Fm. and the base of the Murero Fm. (Fig. 3; Leonian to middle Cesaraugusta; uppermost Stage 4 of Cambrian to lower Drumian).
The solenopleurids species recorded in this interval have been reviewed: Parasolenopleura cf. wurmi, Parasolenopleura aculeata, Badulesia tenera, Badulesia granieri, Badulesia paschi, Pardailhania hispida, Pardailhania multispinosa, Pardailhania morisca, and Pardailhania sdzuyi. Some of these species have been used to establish the biozonation of this time interval in the Mediterranean Subprovince (sensu Sdzuy et al., 1999), where they have a wide distribution. Furthermore, Parasolenopleura aculeata and Badulesia tenera have also been recorded in other biogeographical areas such as Baltica or Avalonia, which allows a good correlation with these regions. From the systematic point of view the most relevant aspect is the identification for the first time in the Iberian Chains of Parasolenopleura aculeata and P. cf. wurmi.

On the other hand, the finding at the same stratigraphical order of the FAD species in the sections studied and the systematic review of taxa has allowed us to collate a phylogenetic proposal for the basal genera of the Solenopleuropsinae Subfamily: Badulesia and Pardailhania, whose ancestor would be Parasolenopleura aculeata (Fig. 7).

In accordance with this phylogenetic proposal, the previous biozonation for the lower and middle Caesaraugustian has been redefined and characterized, with four phylozones (Fig. 1): Badulesia tenera, Badulesia granieri, Pardailhania hispida, and Pardailhania multispinosa. This zonation is widely recognizable in Spain and France. Badulesia and Pardailhania superzones have also been defined, which are recognizable throughout the Mediterranean region and allow a precise correlation in this area and, occasionaly, with other biogeographical regions such as Baltica and Avalonia.

\section{ACKNOWLEDGEMENTS}

We thank Dr. I. Korovnikov (Novosibirsk) and an anonymous reviewer for valuable suggestions on the manuscript. This is a contribution to the GIUV2017-395 Research Group of the Universitat de València. This work is a contribution to the IGCPs 652 and 668. Thanks due to Ms. Isabel Pérez Urresti (technician of the University of Zaragoza) who assisted us with the figures, and to Dr Jorge Esteve for his comments on the manuscript.

\section{REFERENCES}

Álvaro, J.J. 1996. Nuevos trilobites del Cámbrico Medio de las Cadenas Ibéricas (NE España). Revista Española de Paleontología, 11, 75-82. 
Álvaro, J.J. \& Vizcaïno, D. 1997. Révision des Trilobites Solenopleuropsinae du Cambrien moyen de la Montagne Noire (France). Geobios, 30, 541-561; doi: 10.1016/ S0016-6995(97)80121-0.

Álvaro, J.J. \& Vizcaïno, D. 1998. Révision biostratigraphique du Cambrien moyen du versant méridional de la Montagne Noire (Languedoc, France). Bulletin de la Société Géologique de France, 169, 233-242.

Álvaro, J.J. \& Vizcaïno, D. 2000. Nouvel assemblage de trilobites dans le Cambrien moyen de la nappe de Pardailhan (Montagne Noire, France): implications biostratigraphiques dans la région méditerranéenne. Eclogae Geologicae Helvetiae, 93, 277-289; doi: 10.5169/ seals-168822.

Álvaro, J.J. \& Vizcaïno, D. 2001. Evolutionary trends in the ornamentation of Cambrian Solenopleuropsinae Trilobites. Palaeontology, 44, 131-141; doi: 10.1111/14754983.00173.

Álvaro, J.J., Vizcaïno, D. \& Vennin, E. 1999. Trilobite diversity patterns in the Middle Cambrian of southwestern Europe: a comparative study. Palaeogeography, Palaeoclimatology, Palaeoecology, 151, 241-254; doi: 10.1016/S00310182(99)00033-4.

Álvaro, J.J., Lefebvre, B. \& Vizcaïno, D. 2001. Catalogue of the fossil species defined in the Lower Paleozoic of the southern Montagne Noire. Annales Société Géologique du Nord (2éme série), 8, 227-232.

Angelin, N.P. 1851. Palceontologica Svecica. Pars I; Iconographia Crustaceorum Formtionis Transitionis. Fasc. 1, 1-24, Academie Regiae Scientarium Suecanae, Holmiæ.

Angelin, N.P. 1854. Palceontologica Scandinavica. Pars II; Crustacea Formationis Transitionis. Fasc. 2, i-ix, 21-92, Academie Regiae Scientarium Suecanae, Holmiæ.

Angelin, N.P. 1878. Palceontologica Svecica. Pars I; Crustacea Formationis Transitionis. Fasciculi I \& II, x+96 pp. Academie Regiae Scientarium Suecanae, Holmiæ.

Axheimer, N. \& Ahlberg, P. 2003. A core drilling through Cambrian strata at Almbacken, Scania, S. Sweden: trilobites and stratigraphical assessment. Geologiska Föreningens i Stockholm Förhandlingar, 125, 139-156; doi: 10.1080/11035890301253139.

Babcock, L.E. 1994. Systematics and phylogenetics of polymeroid trilobites from the Henson Gletscher and Kap Stanton formations (Middle Cambrian), North Greenland. Bulletin Grønlands geologiske Undersøgelse, 169, 79-127.

Barrande, J. 1846. Notice Préliminaire sur le Système Silurien et les Trilobites de Bohême. Hirschfeld, Leipzig vi+1-96.

Bengtson, S. \& Fletcher, T.P. 1983. The oldest sequence of skeletal fossils in the Lower Cambrian of southeastern Newfoundland. Canadian Journal of Earth Sciences, 20, 525-536; doi: 10.1139/e83-050.

Bergeron, J. 1889. Étude géologique du Massif ancien situé au Sud du Plateau Central. Annales des Sciences Géologiques, 22, IV+1-361.

Billings, E. 1865. Palceozoic Fossils. Volume 1. Containing Descriptions and Figures of New or Little Known Species of Organic Remains from the Silurian Rocks. 1861-1865. Geological Survey of Canada, Montreal, $426 \mathrm{pp}$.
Brøgger, W.C. 1878. Om Paradoxidesskifrene ved Krekling. Nyt Magazin for Naturvidenskaberne, 24, 18-88.

Canudo, J.I. 2018. The collection of type fossils of the Natural Science Museum of the University of Zaragoza (Spain). Geoheritage, 10, 385-392; doi: 10.1007/s12371017-0228-1.

Chirivella Martorell, J.B. 2008. Sistemática de los trilobites, bioestratigrafía y paleoecología del límite LeonienseCaesaraugustiense (Cámbrico Medio) en las Cadenas Ibéricas (NE de España). Ph.D. Thesis, Universitat de València, Spain (unpublished). 226 pp.

Chirivella Martorell, J.B., Gozalo, R. \& Liñán, E. 2003. Estudio taxonómico y biométrico de Badulesia tenera (Hartt in Dawson, 1868), Trilobita. Caesaraugustiense (Cámbrico Medio) de las Cadenas Ibéricas (NE de España). Revista Española de Paleontología, 18, 83-101.

Chirivella Martorell, J.B., Liñán, E., Ahlberg, P. \& Gozalo, R. 2015. A blind trilobite with Baltic affinities from Cambrian Series 3 of the Iberian Chains, Spain, and its stratigraphical and palaeobiogeographical significance. GFF, 137, 175 180; doi: 10.1080/11035897.2015.1061593.

Chirivella Martorell, J.B., Liñán, E., Dies Álvarez, M.E. \& Gozalo, R. 2017. Bailiaspis (Trilobita) with English affinities from the Mansilla Formation (Cambrian Series 3 of the Iberian Chains; NE Spain). Spanish Journal of Palaeontology, 32, 17-26; doi: 10.7203/sjp.32.1. 17027.

Courtessole, R. 1973. Le Cambrien Moyen de la Montagne Noire. Biostratigraphie. Imprim. d'Oc, Toulousse, 248 pp.

Dawson, J.W. 1868. Acadian Geology. The Geological Structure, Organic Remains and Mineral Resources of Nova Scotia, New Brunswick, and Prince Edward Island. Macmillan, $2^{\text {nd }} e d .$, London xxvi+694 pp.

Dean, W.T. 2005. Trilobites from the Çal Tepe Formation (Cambrian), Near Seydisehir, Central Taurides, Southwestern Turkey. Turkish Journal of Earth Sciences, $14,1-71$.

Dean, W.T. 2006. Cambrian stratigraphy and triobites of the Samur Dag Area, South of Hakkâri, Southeastern Turkey Turkish Journal of Earth Sciences, 15, 225-257.

Dean, W.T. \& Krummenacher, R. 1961. Cambrian Trilobites from the Amanos Mountains, Turkey. Palaeontology, 4, 71-81.

Dean, W.T. \& Monod, O. 1997. Cambrian development of the Gondwanaland margin in southeastern Turkey. Turkish Association of Petroleum Geologists. Special Publication, $3,61-74$.

Dean, W.T. \& Özgül, N. 1981. Middle Cambrian trilobite succession in the Çaltepe Formation at Bagbasi (HadimKonya) central Taurus. Bulletin Mineral Research \& Exploration Institute of Turkey, 92 (year 1979), 1-6.

Dean, W.T., Monod, O. \& Günay, Y. 1986. Lower Paleozoic stratigraphy in the southern and central Amanos Mountains, south central Turkey. Geological Magazine, 122, 215-226; doi: 10.1017/S0016756800034713.

Dies, M.E. \& Gozalo, R. 2004. Agnostida (Trilobita) de la Formación Valdemiedes (Leoniense: Cámbrico Medio basal) de las Cadenas Ibéricas (NE de España). Boletín Geológico y Minero, 115, 683-98. 
Dies, M.E., Gozalo, R. \& Liñán, E. 2004. Zonación del límite Bilbiliense-Leoniense (Formación Valdemiedes, Cámbrico Inferior-Medio) en las Cadenas Ibéricas. GeoTemas, 6(2), 283-286.

Esteve, J. 2013. Revisión del enrollamiento en los trilobites del Cámbrico español y su implicación en la evolución de los trilobites. Estudios Geológicos, 69, 209-225; doi: 10.2989/egeol.41337.272.

Esteve, J., Gozalo, R., Liñán, E. \& Chirivella Martorell, J.B. 2008. Pardailhania Thoral, 1947 (Solenopleuropsinae, Trilobita) from Caesaraugustan (Middle Cambrian) of the Iberian Chains (NE Spain). Cuadernos del Museo Geominero, 9, 99-103.

Esteve, J., Zamora, S., Gozalo, R. \& Liñán, E. 2010. Sphaeroidal enrolment in middle Cambrian solenopleuropsinae trilobites. Lethaia, 43, 478-493; doi: 10.1111/j.1502-3931.2009.00205.x.

Fletcher, T.P. 2005. Holaspid variation in the solenopleurid trilobite Parasolenopleura gregaria (Billings, 1865) from the Cambrian of Newfoundland. Palaeontology, 48, 1075-1089; doi: 10.1111/j.1475-4983.2005.00494.x.

Fletcher, T.P. 2006. Bedrock geology of the Cape St. Mary's Peninsula, southwest Avalon Peninsula, Newfoundland (includes parts of NTS maps sheets 1M/1, 1N/4, 1L/6 and $1 \mathrm{~K} / 13$ ), Newfoundland. Government of Newfoundland and Labrador, Geological Survey, Department of Natural Resources Report, 06-02, 1-117.

Gámez Vintaned, J.A. \& Mayoral, E. 1992. Primeras aportaciones a la Paleoicnología del Grupo Murero (Cámbrico Inferior-Medio) en Murero (Provincia de Zaragoza. Cadena Ibérica Occidental). Geogaceta, 12, 100-102.

Gámez Vintaned, J.A. \& Mayoral, E. 1995. Paleoicnología del Grupo Mesones (Cámbrico Inferior-Medio) en Murero (Cadena Ibérica Occidental, NE de España). In: Memorias de las IV Jornadas Aragonesas de Paleontología: "La Expansión de la Vida en el Cámbrico” (eds. Gámez Vintaned, J.A. \& Liñán, E.). Institución "Fenando el Católico", Zaragoza, 219-252.

Gámez Vintaned, J.A. \& Zhuravlev, A.Y. 2018. Comment on "Aysheaia prolata from the Utah Wheeler Formation (Drumian, Cambrian) is a frontal appendage of the radiodontan Stanleycaris" by Stephen Pates, Allison C. Daley, and Javier Ortega-Hernández. Acta Palaeontologica Polonica, 63, 103-104; doi: 10.4202/app.00335.2017.

Gámez Vintaned, J.A., Fernández-Nieto, C., Gozalo, R., Liñán, E., Mandado, J. \& Palacios, T. 1991. Bioestratigrafía y evolución ambiental del Cámbrico de Borobia (Provincia de Soria, Cadena Ibérica Oriental). Cuadernos do Laboratorio Xeolóxico de Laxe, 16, 251271.

Gámez Vintaned, J.A., Liñán, E. \& Zhuravlev, A.Y. 2011. A New Early Cambrian Lobopod-Bearing Animal (Murero, Spain) and the Problem of the Ecdysozoan Early Diversification. In: Evolutionary Biology - Concepts, Biodiversity, Macroevolution and Genome Evolution (ed. Pontarott, P.I.). Springer-Verlag, Berlin, Heidelberg, 193-219.
García-Bellido, D.C., Gozalo, R., Chirivella Martorell, J.B. \& Liñán, E. 2007. The Demosponge genus Leptomitus and a new species from the Middle Cambrian of Spain. Palaeontology, 50, 467-478; doi: 10.1111/j.14754983.2007.00635.x.

García-Bellido, D.C., Dies Álvarez, M.E., Gámez Vintaned, J.A., Liñán, E. \& Gozalo, R. 2011. First report of Crumillospongia (Demospongea) from the Cambrian of Europe (Murero biota, Spain). Bulletin of Geosciences, 86, 641-650; doi: 10.3140/bull.geosci.1253.

Geyer, G. 2017. Trilobites of the Galgenberg Member (Tannenknock Formation), middle Cambrian Stage 5, Franconian Forest, Germany: a paradigmatic lowermost middle Cambrian West Gondwanan fauna. Paläontologische Zeitschrift, 91, 5-70; doi: 10.1007/s12542-017-0339-7.

Geyer, G. \& Landing, E. 2001. Middle Cambrian of Avalonian Massachusetts: stratigraphy and correlation of the Braintree trilobites. Journal of Paleontology, 75, 116-135; doi: 10.1666/0022-3360(2001)075<0116:MCO AMS>2.0.CO;2.

Geyer, G. \& Landing, E. 2004. A unified Lower-Middle Cambrian chronostratigraphy for West Gondwana. Acta Geologica Polonica, 54, 179-218.

Geyer, G. \& Landing, E. 2006a. Latest Edicaran and Cambrian of the Moroccan Atlas regions. Beringeria, Special Issue, 6, 7-46.

Geyer, G. \& Landing, E. 2006b. Edicaran-Cambrian depositional environments and stratigraphy of the western Atlas regions. Beringeria, Special Issue, 6, 47-112.

Geyer, G., Landing, E. \& Heldmaier, W. 1995. Faunas and depositional environments of the Cambrian of the Moroccan Atlas regions. Beringeria, Special Issue, 2, 47-119.

Ghienne, J.-F., Monod, O., Kozlu, H. \& Dean, W.T. 2010. Cambrian-Ordovician depositional sequences in the Middle East: A perspective from Turkey. Earth-Science Reviews, 101, 101-146; doi: 10.1016/j.earscirev.2010.04.004.

Gozalo, R. 2017. El yacimiento Cámbrico de Murero (prov. de Zaragoza) ejemplo de convergencia entre ciencia y patrimonio. Monografias de la Real Academia de Ciencias Exactas, Físicas, Químicas y Naturales de Zaragoza, 41, 83-108.

Gozalo, R. \& Liñán, E. 1988. Los materiales hercínicos de la Cordillera Ibérica en el contexto del Macizo Ibérico. Estudios Geológicos, 44, 399-404; doi: 10.3989/ egeol.88445-6556.

Gozalo, R. \& Liñán, E. 1996. Nueva especie de Conocoryphidae (Trilobita). Cámbrico Medio de las Cadenas Ibéricas (NE de España). Revista Española de Paleontología, 11, 247250.

Gozalo, R., Liñán, E. \& Álvaro, J. 1993. Bioestratigrafía del Cámbrico Medio de Villafeliche (Prov. Zaragoza, España). Revista Española de Paleontología $\mathrm{n}^{\mathrm{o}}$ Extraordinario, 49-57.

Gozalo, R., Liñán, E. \& Sdzuy, K. 1996. The Lower and Middle Cambrian of Murero and Villafeliche (West Asturian-Leonese Zone. Western Iberian Chain). In: Field Trip Guide and Abstracts. II Field Conference 
of the Cambrian Stage Subdivision Working Groups. International Subcommision on Cambrian Stratigraphy. Spain. 13-21 September 1996. (eds. Liñán, E., Gámez Vintaned, J.A. \& Gozalo, R.). Universidad de Zaragoza, Zaragoza, 73-80.

Gozalo, R., Dies, M.E. \& Chirivella, J.B. 2004. New occurrence of the family Hipponicharionidae (Bradoriida, Arthropoda), in the lower and middle Cambrian of the Cadenas Ibéricas, Spain. Geobios, 37, 191-197; doi: 10.1016/j.geobios.2003.04.001.

Gozalo, R., Liñán, E., Dies Álvarez, M.E., Gámez Vintaned, J.A. \& Mayoral, E. 2007. The Lower-Middle Cambrian boundary in the Mediterranean subprovince. Geological Society of America Special Paper, 423, 359-373; doi: 10.1130/2007.2423(17).

Gozalo, R., Liñán, E., Gámez Vintaned, J.A., Dies Álvarez, M.E., Chirivella Martorell, J.B., Zamora, S., Esteve, J. \& Mayoral, E. 2008. The Cambrian of the Cadenas Ibéricas (NE Spain) and its trilobites. Cuadernos del Museo Geominero, 9, 137-151.

Gozalo, R., Bernárdez, E., Chirivella Martorell, J.B. \& Liñán, E. 2011a. Trilobites del Cámbrico medio del Cueto Negro (Asturias, NE de España). Boletín Geológico y Minero, 122, 71-82.

Gozalo, R., Chirivella Martorell, J.B., Esteve, J. \& Liñán, E. 2011b. Proposal of correlation between the base of Drumian Stage and the base of middle Caesaraugustan Stage in the Iberian Chains (NE Spain). Bulletin of Geosciences, 86, 545-554; doi: 10.3140/bull.geosci.1254.

Gozalo, R., Dies Álvarez, M.E., Gámez Vintaned, J.A., Zhuravlev, A.Y., Bauluz, B., Subías, I., Chirivella Martorell, J.B., Mayoral, E., Gursky, H.-J., Andrés, J.A. \& Liñán, E. 2013. Proposal of a reference section and point for the Cambrian Series 2-3 boundary in the Mediterranean subprovince in Murero (NE Spain) and its intercontinental correlation. Geological Journal, 48, 142-155; doi: 10.1002/gj.1330.

Gozalo, R., Dies Álvarez, M.E., Gámez Vintaned, J.A., Chirivella Martorell, J.B. \& Liñán, E. 2018. Presence of Naraoia Walcott, 1912 (Nektaspida, Arthropoda) in the middle Cambrian of Europe (Murero, NE Spain). Spanish Journal of Palaeontology, 33, 83-88; doi: 10.7203/ sjp.33.1.13243.

Heuse, T., Blumenstengel, H., Elicki, O., Geyer, G., Hansch, W., Maletz, J., Sarmiento, G.N. \& Weyer, D. 2010. Biostratigraphy - The faunal province of the southern margin of the Rheic Ocean. In: Pre-Mesozoic Geology of Saxo-Thuringia - From the Cadomian Active Margin to the Variscan Orogen. (eds. Linnemann, U. \& Romer, R.L.). Schweizerbart, Stuttgart, 99-170.

Hicks, H. 1872. On some undescribed fossiles from the Menevian Group. Quartely Journal of the Geological Society of London, 28, 173-185; doi: 10.1144/GSL. JGS.1872.028.01-02.17.

Landing, E., Johnson, S.C. \& Geyer, G. 2008. Faunas and Cambriam volcanism on the Avalonian marginal platform, Southern New Brunswick. Journal of Paleontology, 82, 884-905; doi: 10.1666/07-007.1.
Lake, P.H. 1940. A monograph of the British Cambrian Trilobites. Palaeontographical Society, 1940, 273-306.

Lesley, J.P. 1889. A dictionary of the Fossils of Pennsylvania and neighboring states named in the Reports and Catalogues of the Survey. Geological survey of Pennsylvania, Report, 4, XIV+438+XXX1.

Linnarsson, J.G.O. 1879. Om faunan i kalken med Conocoryphe exsulans ("Coronatuskalken"). Sveriges Geologiska Undersökning (C), 35, 1-31.

Linnarsson, J.G.O. 1883. De undre Paradoxideslagren vid Andrarum. Sveriges Geologiska Undersökning (C), 54, $1-48$.

Liñán Guijarro, E. 1978. Bioestratigrafía de la Sierra de Córdoba. Tesis de la Universidad de Granada, 191, 1-112.

Liñán, E. \& Gozalo, R. 1986. Trilobites del Cámbrico inferior y medio de Murero (Cordillera Ibérica). Memorias del Museo Paleontológico de la Universidad de Zaragoza, 2, 1-104.

Liñán, E. \& Mergl, M. 2001. Lower and Middle Cambrian brachiopods from the Iberian Chains and Sierra Morena (Spain). Revista Española de Paleontología, 16, 317-337.

Liñán, E. \& Sdzuy, K. 2001. Trilobites del Cámbrico Medio de Cuevas del Sil (Noroeste de España). In: La Era Paleozoica. El Desarrollo de la Vida Marina. Homenaje al Profesor Jaime Truyols (eds Gámez, J.A. \& Liñán, E.). Institución "Fernando el Católico", Zaragoza. 251-265.

Liñán, E., Gozalo, R., Gámez, J.A. \& Álvaro, J.J. 1992. Las Formaciones del Grupo Mesones (Cámbrico InferiorMedio) en las Cadenas Ibéricas. III Congreso Geológico de España, Actas, 1, 517-523.

Liñán, E., Perejón, A. \& Sdzuy, K. 1993. The LowerMiddle Cambrian stages and stratotypes from the Iberian Peninsula: a revision. Geological Magazine, 130, 817-833; doi: 10.1017/S0016756800023189.

Liñán, E., Gámez Vintaned, J.A., Palacios, T., Álvaro, J.J., Gozalo, R., Mayoral, E., Moreno-Eiris, E., Perejón, A., Quesada, C. \& Sánchez García, T. 1995a. The Cambrian of the Alconera unit. In: XIII Geological Meeting on the West of the Iberian Peninsula. Pre-Conference Field Guide: Neoproterozoic-Cambrian Transect of Sierra Morena and Montes de Toledo Spain. (eds Rodríguez Alonso, M.D. \& Alonso Gavilán, G.). Universidad de Salamanca, Salamanca, 9-21.

Liñán, E., Álvaro, J.J., Gozalo, R., Gámez-Vintaned, J.A. \& Palacios, T. 1995b. El Cámbrico Medio de la Sierra de Córdoba (Ossa-Morena, S de España): trilobites y paleoicnología. Implicaciones bioestratigráficas y paleoambientales. Revista Española de Paleontología, 10, 219-238.

Liñán, E., Perejón, A., Palacios, T., Moreno-Eiris, E. \& Gozalo, R. 1996a. September 15. The Cambrian of the Alconera Unit (Ossa-Morena Zone. Sierra Morena, Badajoz province). In: Field Trip Guide and Abstracts. II Field Conference of the Cambrian Stage Subdivision Working Groups. International Subcommision on Cambrian Stratigraphy. Spain. 13-21 September 1996. (eds Liñán, E., Gámez Vintaned, J.A. \& Gozalo, R.). Universidad de Zaragoza, Zaragoza, 33-43. 
Liñán, E., Sdzuy, K., Álvaro, J.J., Gámez Vintaned, J.A. \& Gozalo, R. 1996b. September 19. The Jarque section: Lower and Middle Cambrian (West Asturian-Leonese Zone. Eastern Iberian Chain). In: Field Trip Guide and Abstracts. II Field Conference of the Cambrian Stage Subdivision Working Groups. International Subcommision on Cambrian Stratigraphy. Spain. 13-21 September 1996. (eds Liñán, E., Gámez Vintaned, J.A. \& Gozalo, R.). Universidad de Zaragoza, Zaragoza, 57-72.

Liñán, E., Villas, E., Gámez-Vintaned, J.A., Álvaro, J.J., Gozalo, R., Palacios, T. \& Sdzuy, K. 1996c. Síntesis paleontológica del Cámbrico y Ordovícico del Sistema Ibérico (Cadenas Ibéricas y Cadenas Hespéricas). Revista Española de Paleontología $\mathrm{n}^{\circ}$ Extraordinario, 21-32.

Liñán, E., Gozalo, R., Palacios, T., Gámez Vinaned, J.A., Ugidos, J.M. \& Mayoral, E. 2002. Cambrian. In: The Geology of Spain (eds Gibbons, W. \& Moreno, T.). The Geological Society, London, 17-29.

Liñán, E., Perejón, A., Gozalo, R., Moreno-Eiris, E. \& Oliveira, J.T. de 2004. The Cambrian System in Iberia. Publicaciones del Instituto Geológico y Minero de España. Serie: Cuadernos del Museo Geominero 3, 63 pp.

Liñán, E., Gozalo, R., Dies Álvarez, M.E., Gámez Vintaned, J.A., Mayoral, E., Chirivella Martorell, J.B., Esteve, J., Zamora, S., Zhuravlev, A.Y. \& Andrés, J.A. 2008. Fourth International Trilobite Conference Trilo 08 Toledo, Spain, 2008. Post-Conference Field Trip. Lower and Middle Cambrian trilobites of selected localities in Cadenas Ibéricas (NE Spain). Universidad de Zaragoza, $52 \mathrm{pp}$.

Loi, A., Pillola, G.L. \& Leone, F. 1995. The Cambrian and Early Ordovician of south-western Sardinia. Rediconti del Seminario della Facoltà di Scienze dell'Univeristà di Cagliari suppl, 65, 61-81.

Martin, F. \& Dean, W.T. 1988. Middle and Upper Cambrian Acritarch and Trilobite zonation at Manuels river and Random island, Eastern Newfoundland. Bulletin of Geological Survey of Canada, 381, 1-91.

Matthew, G.F. 1883. Illustrations of the fauna of the St. John Group, No. 1, The Paradoxides. Transactions of the Royal Society of Canada, section 3, 1, 271-279.

Matthew, G.F. 1888. Illustrations of the fauna of the St. John Group. No. IV.- Part I. Description of a new species of Paradoxides (Paradoxides regina). Part II. The smaller trilobites with eyes (Ptychoparidæ and Ellipsocephalidæ). Transactions of the Royal Society of Canada, section 4, 5 (1887), 115-166.

Matthew, G.F. 1897. Studies on Cambrian faunas. Part I.On a new sub-fauna of the Paradoxides beds of the St. John Group. Part II.- Billings' primordial fossils from Vermont and Labrador. Transactions of the Royal Society of Canada, section 4, 2nd. Series, 3, 165-211.

Meléndez, B. \& Asensio Amor, I. 1964. El yacimiento de trilobites del Cámbrico medio de Presa. (Monte Pruida, Castropol, Asturias). Boletín del Instituto de Estudios Asturianos (suplemento de Ciencias), 10, 3-11.

Mergl, M. \& Liñán, E. 1986. Some Cambrian Brachiopoda of the Cordillera Iberica and their biostratigraphical significance. Memorias I Jornadas de Paleontología, Zaragoza, 159-180.

Mergl, M. \& Zamora, S. 2012. New and revised occurrences of rhynchonelliformean brachiopods from the middle Cambrian of the Iberian Chains, NE Spain. Bulletin of Geosciences, 87, 571-586; doi: 10.3140/bull.geosci.1327.

Miquel, J. 1905. Essai sur le Cambrien de la Montagne Noire. Coulouma- l'Acadien. Bulletin de la Sociéte Géologique de France, $4^{\text {eme }}$ serie, 5, 465-483.

Morris, S.F. 1988. A review of British trilobites, including a synoptic revision of Salter's monograph. Monograph of the Palaeontographical Society, 140, $316 \mathrm{pp}$.

Neben, W. \& Krüger, H.H. 1979. Fossilien kambrischer, ordovizischer und silurischer Geschiebe. Staringia, 5, $1-63$.

Palacios, T. 1982. El Cámbrico entre Viniegra de Abajo y Mansilla (Sierra de la Demanda, Logroño). Trilobites e Icnofósiles. Biblioteca de Estudios Riojanos, Logroño, $85 \mathrm{pp}$.

Palacios, T. 2015. Acritarch assemblages from the Oville and Barrios Formations, northern Spain: A pilot proposal of a middle Cambrian (Series 3) acritarch biozonation in northwestern Gondwana. Review of Palaeobotany and Palynology, 219, 71-105; doi: 10.1016/j.revpalbo.2015.03.008.

Pates, S. \& Daley, A.C. 2017. Caryosyntrips: A radiodontan from the Cambrian of Spain, USA and Canada. Papers in Palaeontology, 3, 461-470; doi: 10.1002/spp2.1084.

Pompeckj, J.F. 1901. Versteinerungen der ParadoxidesStufe von La Cabitza in Sardinien und Bemerkungen zur Gliederung des sardischen Cambrium. Zeitschrift der deutschen geologische Gesellschaft, 53, 1-23.

Rasetti, F. 1972. Cambrian trilobite faunas of Sardinia. Atti della Accademia Nazionale dei Lincei, Memoire, serie, 8, 11, 1-98.

Raymond, P. 1937. Upper Cambrian and Lower Ordovician Trilobita and Ostracoda from Vermont. Geological Society of America Bulletin, 48, 1079-1146; doi: 10.1130/GSAB48-1079.

Resser, C.E. 1937. New Species of Cambrian Trilobites of the family Conocoryphidae. Journal of Paleontology, $11,39-42$.

Robison, R.A. 1964. Late Middle Cambrian faunas from western Utah. Journal of Paleontology, 38, 510-566.

Rudoph, F. 1994. Die Trilobiten der Mittelkambrischen Geschiebe. Verlag Frank Rudolph, Wankedorf, 1-309 pp.

Rushton, A.W.A. 1966. The Cambrian Trilobites from the Purley Shales of Warwickshire. Paleontological society Monographs, London, 1-55 pp.

Schmidt, E.W. 1942. Die mittelkambrische Fauna von Doberlug. Jahrbuch des Reichsamts für Bodenforschung, 62, 344-402.

Schöning, H. 2002. Trilobiten aus Geschieben des Kies-Sand-Rückens in der Laerheide (Landkreis Osnabrück)- I. Kambrische Trilobiten. Osnabrücker Naturwissenschaftliche Mitteilungen, 28, 71-88.

Sdzuy, K. 1957. Revision der mittelkambrischen Trilobiten von Doberlug. Senckenbergiana lethaea, 38, 7-28. 
Sdzuy, K. 1958. Neue Trilobiten aus dem Mittelkambrium von Spanien. Senckenbergiana lethaea, 39, 235-253.

Sdzuy, K. 1961. Das Kambrium Spaniens. Teil II: Trilobiten. Akademie der Wissenschaften und der Literatur Abhandlungen der MathematischNaturwissenschaftililichen Klasse 1961 (7-8), 217-408.

Sdzuy, K. 1966. Das Kambrium des Frankenwaldes. 2. Die Bergleshof-Schichten und ihre Trilobiten-Fauna. Senckenbergiana lethaea, 47, 57-86.

Sdzuy, K. 1968. Trilobites del Cámbrico Medio de Asturias. Trabajos de Geología, Universidad de Oviedo, 1 (1967), 77-133.

Sdzuy, K. 1969. Bioestratigrafía de la Griotte Cámbrica de los Barrios de Luna (León) y de otras sucesiones comparables. Trabajos de Geología, Universidad de Oviedo, 2 (1968), 45-58.

Sdzuy, K. 1970. Mittelkambrische Fossilien aus neuen Bohrungen bei Doberlug und bei Delitzsch. Geologie, 19, 1066-1091.

Sdzuy, K. 1971. La subdivisión bioestratigráfica y la correlación del Cámbrico Medio de España. I Congreso Hispano-Luso-Americano de Geología Económica, Sección 1 Geología, 2, 769-782.

Sdzuy, K. 1972. Das Kambrium der acadobaltischen Faunenprovinz. Zentralblatt für Geologie und Paläontologie, Teil II, 1972, 1-91.

Sdzuy, K., Liñán, E. \& Gozalo, R. 1996. The Middle Cambrian Series. In: Field Trip Guide and Abstracts. II Field Conference of the Cambrian Stage Subdivision Working Groups. International Subcommision on Cambrian Stratigraphy. Spain. 13-21 September 1996. (eds Liñán, E., Gámez Vintaned, J.A. \& Gozalo, R.). Universidad de Zaragoza, Zaragoza, 16-18.

Sdzuy, K., Liñán, E. \& Gozalo, R. 1999. The Leonian Stage (early Middle Cambrian): a unit for Cambrian correlation in the Mediterranean subprovince. Geological Magazine, 136, 39-48; doi: 10.1017/S0016756899002241.

Sender, L.M., Gozalo, R., Liñán, E., Dies, M.E. \& Martín, E. 1999. Trilobites del Cámbrico Medio de Monforte de Moyuela (Teruel). Temas Geológico-Mineros ITGE, 26, 344-349.

Shergold, J.H. \& Sdzuy, K. 1984. Cambrian and Early Tremadocian trilobites from Sultan Dag, Central Turkey. Senckenbergiana lethaea, 65, 51-135.
Shimer, H.W. \& Shrock, R.R. 1944. Index Fossils of North America. The Masschusetts Institute of Technology Press, Cambridge, 1-837 pp.

Šnajdr, M. 1958. Trilobiti českého středního kambria. Rozpravy Ústředního ústavu geologického, 24, 1-280.

Strand, T. 1929. The Cambrian beds of the Mjøsen district in Norway. Norsk Geologisk Tidsskrift, 10, 308-365.

Swinnerton, H.H. 1915. Suggestions for a revised classification of trilobites. Geological Magazine, new series, 2, 407-496, 538-545; doi: 10.1017/S0016756800203737.

Thoral, M. 1935. Contribution à l'Etude Paléontologique de l'Ordovicien Inférieur de la Montagne Noire et Révision Sommaire de la Faune Cambrienne de la Montagne Noire. Imprimerie de la Charité, Montpellier, 362 pp.

Thoral, M. 1946. Conocoryphidae Languedociens. Annales de l'Université de Lyon, série 3, section C, Sciences Natureles, 4, 1-74.

Thoral, M. 1947. Trois nouveaux genres des Trilobites acadiens du Languedoc et d'Espagne. Comptes Rendus de l'Académie des Sciences Paris, 224, 59-60.

Thoral, M. 1948. Solenopleuridae et Liostracidae. Annales de l'Université de Lyon, série 3, section C, Sciences Natureles, 5, 5-89.

Verneuil, E. 1862. Descubrimiento de la fauna primordial en la provincia de Zaragoza. Revista Minera, 13, 479.

Walcott, C.D. 1884. On the Cambrian faunas of North America. U.S. Geological Survey, Bulletin, 10, 289-355.

Walcott, C.D. 1913. The Cambrian trilobites in China. In Research in China. Carnegie Institute, 54, 1-276.

Weidner, T. \& Nielsen, A.T. 2009. The Middle Cambrian Paradoxides paradoxissimus Superzone on Öland, Sweden. GFF, 131, 253-268; doi: 10.1080/11035890903189827.

Westergård, A.H. 1953. Non-Agnostidean Trilobites of the Middle Cambrian of Sweden. III. Sveriges Geologiska Undersökning (C), 526, 1-48.

Wheeler, R.R. 1942. New Mid-Cambrian Ptychoparid. American Journal of Science, 240, 567-570; doi: 10.2475/ ajs.240.8.567.

Wiman, C. 1906. Palaeontologische Notizen. 7. Über das Exsulanslager auf Öland. Bulletin of the Geological Institution of the University of Uppsala, 7, 287-291.

Zamora, S. 2010. Middle Cambrian echinoderms from north Spain show echinoderms diversified earlier in Gondwana. Geology, 38, 507-510; doi: 10.1130/G30657.1. 
